

\section{What is the Current Formal Legal Environment for Foreign Companies in China in the Light of the Phase 1 Trade Agreement?}

\section{Intellectual Property Rights (IPRs) Protections for Foreign Direct Investment (FDI) in Mainland China}

\section{Mei Lin Lyu}

\section{Abstract}

This thesis employs doctrinal legal analysis methods by using laws, regulations and legal theories, to evaluate the current protections of intellectual property rights for foreign investors in mainland China. In this thesis, it compares the current Chinese laws and regulations on intellectual property protections with its international Fair and Equitable Treatment principles, previous laws, and Phase 1 Trade Agreement. It concludes that Phase 1 Trade Agreement has been implemented mostly in the current Chinese laws, which also have been improved fundamentally to protect foreign investors' interests and rights. However, given the backgrounds on rule of law in China, this thesis also recognises the formations of Chinese laws are different from those perceived by the Western societies. Therefore, even though China has strive to cohere the standards of international investment law, its laws are still relatively lacking in preciseness and predictability, clarity and effective enforcement. 


\section{Table of Contents}

Annex 1: Abbreviations 4

Annex 2: Definitions of Legal Terms 6

Annex 3: Background Conceptual Framework 17

I. Introduction 29

II. Methodology 31

III. Existing Academic Literature 33

IV. The impact of US-China trade war 35

V. Chinese Law 38

VI. Aspects of IP Reforms Comparing the Current Chinese Laws and the Past 55

VII. Implementing Action Plans 61

VIII. Phase 1 Trade Agreement 64

IX. Evaluation $\quad 69$

X. Conclusion 82

XI. Annex 4-13 84

XII. Bibliography 85 
Annex 1: Abbreviations

BIT Bilateral Investment Treaty

CJV Contractual Joint Ventures

CNIPANational Intellectual Property Administration (China)

Competition Law Anti-Unfair Competition Law (China)

CPCC Copyright Protection Centre of China

DSB Dispute Settlement Body

DSM Dispute Settlement Mechanism

DSU Dispute Settlement Understanding

FDI Foreign Direct Investment

FET Fair and Equitable Treatment

FIE Foreign Investment Enterprise

FIL Foreign Investment Law (China)

FTA Free Trade Agreement

FTZ Negative List The Free Trade Zone Special Administrative Measures on Access to Foreign Investment (China)

Further Action Plan Action Plan for Further Implementation of the National IP Strategy

GATT 1994 General Agreement on Tariffs and Trade 1994

GI Geographical Indication

IIA International Investment Agreement

IO International Organization

IP Intellectual Property

IPR Intellectual Property Right

Iron Fist International Property Law Enforcement Action Plan for 2020

JV Joint Venture

MFN Most-Favoured Nation

MOFCOM Ministry of Commerce (China) 
National Negative List The Special Administrative Measures on Access to Foreign Investment (China)

NCAC National Copyright of Administration China

New Evidence Provisions Amendments to Several Provisions of the Supreme People's Court on Evidence for Civil Litigation

NPC National Peoples' Congress (China)

PBOC People's Bank of China

PFTZ Pilot Free Trade Zone

Positive List The Catalogue of Encouraged Industries for Foreign Investment (China)

RMB Renmibi (Chinese currency)

SAFE State Administration of Foreign Exchange

SAMR State Administration for Market Regulation (China)

SPC Supreme People's Court

The competent department The competent department of foreign trade and economic cooperation

TIER Technology Import and Export Regulations

TRIPs Trade-Related Aspects of Intellectual Property Rights

USTR United Stated Trade Representative

VIE Variable Interest Equity

WTO World Trade Organization 
Annex 2: Definitions of Legal Terms

(1) FTA: a pact between two or more nations to reduce barriers with little or no government tariffs, quotas, subsidies or prohibitions to inhibit their exchange of goods and services.

(2) Cyber Theft

: THEFT MAY ARISE IN A VARIETY OF CIRCUMSTANCES, INCLUDING THOSE INVOLVING DEPARTING EMPLOYEES TAKING PORTABLE STORAGE DEVICES CONTAINING TRADE SECRETS, FAILED JOINT VENTURES, CYBER INTRUSION AND HACKING, AND MISUSE OF INFORMATION SUBMITTED BY TRADE SECRET OWNERS TO GOVERNMENT ENTITIES FOR PURPOSES OF COMPLYING WITH REGULATORY OBLIGATIONS.

(3) National Treatment

:EACH MEMBER SHALL ACCORD TO THE NATIONALS OF OTHER MEMBERS TREATMENT NO LESS FAVOURABLE THAN THAT IT ACCORDS TO ITS OWN NATIONALS WITH REGARD TO THE PROTECTION OF INTELLECTUAL PROPERTY, SUBJECT TO THE EXCEPTIONS ALREADY PROVIDED IN, RESPECTIVELY, THE PARIS CONVENTION (1967), THE BERNE CONVENTION (1971), THE ROME CONVENTION OR THE TREATY ON INTELLECTUAL PROPERTY IN RESPECT OF INTEGRATED CIRCUITS.

EACH MEMBER SHALL ACCORD TO THE NATIONALS OF OTHER MEMBERS TREATMENT NO LESS FAVOURABLE THAN THAT IT ACCORDS TO ITS OWN NATIONALS WITH REGARD TO THE PROTECTION OF INTELLECTUAL PROPERTY, SUBJECT TO THE EXCEPTIONS ALREADY PROVIDED IN, RESPECTIVELY, THE PARIS CONVENTION (1967), THE BERNE CONVENTION (1971), THE ROME 
CONVENTION OR THE TREATY ON INTELLECTUAL PROPERTY IN RESPECT OF INTEGRATED CIRCUITS

(4) National Treatment of Patents: The Paris Convention provides that, as regards the protection of industrial property, each Contracting State must grant the same protection to nationals of other Contracting States that it grants to its own nationals. Nationals of non-Contracting States are also entitled to national treatment under the Convention if they are domiciled or have a real and effective industrial or commercial establishment in a Contracting State.

(5) MFN Principle: "With regard to the protection of intellectual property, any advantage, favour, privilege or immunity granted by a Member to the nationals of any other country shall be accorded immediately and unconditionally to the nationals of all other Members."

(6) MFN Obligations

:THE POSSIBILITY TO OBTAIN THE PROTECTION BY THE BERNE CONVENTION BY FIRST PUBLICATION OF A WORK IN A COUNTRY OF THE UNION REPRESENTS A REMARKABLE EXTENSION OF SUCH POSSIBILITIES FOR AUTHORS WHO ARE NOT NATIONALS OF A COUNTRY OF THE UNION NOR HAVE THEIR HABITUAL RESIDENCE IN SUCH A COUNTRY.

(7) Reciprocal Tariff concessions

: IN SUCH NEGOTIATIONS AND AGREEMENT, WHICH MAY INCLUDE PROVISION FOR COMPENSATORY ADJUSTMENT WITH RESPECT TO OTHER PRODUCTS, THE CONTRACTING PARTIES CONCERNED SHALL ENDEAVOUR TO MAINTAIN A GENERAL LEVEL OF RECIPROCAL AND MUTUALLY ADVANTAGEOUS CONCESSIONS NOT LESS FAVOURABLE TO TRADE THAN THAT PROVIDED FOR IN THIS AGREEMENT PRIOR TO SUCH NEGOTIATIONS. 
(8) Quantitative Restrictions

: NO PROHIBITIONS OR RESTRICTIONS OTHER THAN DUTIES, TAXES OR OTHER CHARGES, WHETHER MADE EFFECTIVE THROUGH QUOTAS, IMPORT OR EXPORT LICENCES OR OTHER MEASURES, SHALL BE INSTITUTED OR MAINTAINED BY ANY CONTRACTING PARTY ON THE IMPORTATION OF ANY PRODUCT OF THE TERRITORY OF ANY OTHER CONTRACTING PARTY OR ON THE EXPORTATION OR SALE FOR EXPORT OF ANY PRODUCT DESTINED FOR THE TERRITORY OF ANY OTHER CONTRACTING PARTY.

(9) International Minimum Standard: Article 1105 of NAFTA. Article 1105(1) provides that 'Each Party shall accord to investments of investors of another Party treatment in accordance with international law, including fair and equitable treatment and full protection and security.'

(10) Article 47 of Foreign Trade Law (2004)

: WHERE A COUNTRY OR REGION THAT HAS SIGNED OR JOINTLY ACCEDED TO THE ECONOMIC AND TRADE TREATIES OR AGREEMENTS WITH THE PEOPLE'S REPUBLIC OF CHINA VIOLATES THE PROVISIONS OF SUCH TREATIES AND AGREEMENTS AND THUS CAUSES LOSSES OR DAMAGE TO THE INTERESTS THE PEOPLE'S REPUBLIC OF CHINA IS ENTITLED TO UNDER THESE TREATIES AND AGREEMENTS, OR IMPEDES THE ACHIEVEMENT OF THE OBJECTIVES SET IN THE TREATIES AND AGREEMENTS, THE GOVERNMENT OF THE PEOPLE'S REPUBLIC OF CHINA HAS THE RIGHT TO REQUEST THE GOVERNMENT OF THE COUNTRY OR REGION CONCERNED TO TAKE APPROPRIATE REMEDIES MEASURES AND MAY SUSPEND OR TERMINATE ITS PERFORMANCE OF RELEVANT OBLIGATIONS IN COMPLIANCE WITH THE RELEVANT TREATIES AND AGREEMENTS. 
(11) Statement of Administrative Action: „The Statement describes the administrative action proposed to implement the particular chapter of the Agreement, explaining how the proposed action changes existing administrative practice or authorizes further action and stating why such actions are required to implement the Agreement.“

(12) US/Canada Case

: „AS THE APPELLATE BODY HAS EXPLAINED, ARTICLE 23.1 LAYS DOWN THE FUNDAMENTAL OBLIGATION OF WTO MEMBERS TO HAVE RECOURSE TO THE RULES AND PROCEDURES OF THE DSU WHEN SEEKING REDRESS OF A VIOLATION OF THE COVERED AGREEMENTS. ARTICLE 23 RESTRICTS WTO MEMBERS' CONDUCT IN TWO RESPECTS. FIRST, ARTICLE 23.1 ESTABLISHES THE WTO DISPUTE SETTLEMENT SYSTEM AS THE EXCLUSIVE FORUM FOR THE RESOLUTION OF SUCH DISPUTES AND REQUIRES ADHERENCE TO THE RULES OF THE DSU. SECONDLY, ARTICLE 23.2 PROHIBITS CERTAIN UNILATERAL ACTION BY A WTO MEMBER. THUS, A MEMBER CANNOT UNILATERALLY: DETERMINE THAT A VIOLATION HAS OCCURRED, BENEFITS HAVE BEEN NULLIFIED OR IMPAIRED, OR THAT THE ATTAINMENT OF ANY OBJECTIVE OF THE COVERED AGREEMENTS HAS BEEN IMPEDED [...]“

(13) Aim of DSM: „Prompt compliance with recommendations or rulings of the DSB is essential in order to ensure effective resolution of disputes to the benefit of all Members“

(14) Article 21.5 of DSU

: WHERE THERE IS DISAGREEMENT AS TO THE EXISTENCE OR CONSISTENCY WITH A COVERED AGREEMENT OF MEASURES TAKEN TO COMPLY WITH THE RECOMMENDATIONS AND RULINGS SUCH DISPUTE SHALL BE DECIDED THROUGH RECOURSE TO THESE DISPUTE SETTLEMENT PROCEDURES, INCLUDING WHEREVER POSSIBLE RESORT TO THE ORIGINAL PANEL. THE 
PANEL SHALL CIRCULATE ITS REPORT WITHIN 90 DAYS AFTER THE DATE OF REFERRAL OF THE MATTER TO IT. WHEN THE PANEL CONSIDERS THAT IT CANNOT PROVIDE ITS REPORT WITHIN THIS TIME FRAME, IT SHALL INFORM THE DSB IN WRITING OF THE REASONS FOR THE DELAY TOGETHER WITH AN ESTIMATE OF THE PERIOD WITHIN WHICH IT WILL SUBMIT ITS REPORT.

(15) Negative Consensus Basis: „....In other words, any Member intending to block the decision to adopt the report(s) has to persuade all other WTO Members (including the adversarial party in the case) to join its opposition or at least to stay passive.“

(16) The Competent Department

: „TECHNOLOGY IMPORT AND EXPORT IS THE IMPORTANT COMPONENT OF THE COMPETENT DEPARTMENT. THE DEPARTMENT DRAFTS AND IMPLEMENTS the REgulations OF FOREIGN TECHNOLOGY TRADE; REGULATES LEGISLATIONS AND ENCOURAGES REGULATIONS ON TECHNOLOGY EXPORT, DRAFTS NEW AND ADVANCED TECHNOLOGY EXPORT LISTS, RESTRICTIVE AND PROHIBITIVE LISTS, REGULATES TECHNOLOGY AND NEW AND ADVANCED TECHNOLOGY EXPORT; REGULATES TECHNOLOGY IMPORT AND INTERNATIONAL BIDDING, DRAFTS AND IMPLEMENTS NATIONAL TECHNOLOGY EXPORT CONTROL REGULATIONS, CERTIFIES EXPORT LICENSES RELATED TO TECHNOLOGY NON-PROLIFERATION EXPORTS; ORGANISES MULTILATERAL AND BILATERAL INDUSTRIAL AND TECHNICAL COOPERATION; AND IS RESPONSIBLE FOR FOREIGN ECONOMIC AND TRADE DEVELOPMENT, TECHNOLOGY DEVELOPMENT AND SO ON.

Also, it is important to take notice regarding other technology export and import departments, the Competent Department is the main organ in charge, but it is not the only department. For the reason that the national technology import and export 


\section{JOSHA}

Journal of Science, Humanities and Arts

management work is complex and involves a wide range of areas, according to the division of labor of the State Council on the functions of administrative departments, there are also the International Planning Commission, the National Economic and Trade Commission, the Ministry of Science and Technology, and the Ministry of Foreign Affairs in charge.

(17) Fair and Equitable Procedures: as provided in Article 42, TRIPs, s

: MEMBERS SHALL MAKE AVAILABLE TO RIGHT HOLDERS CIVIL JUDICIAL PROCEDURES CONCERNING THE ENFORCEMENT OF ANY INTELLECTUAL PROPERTY RIGHT COVERED BY THIS AGREEMENT. DEFENDANTS SHALL HAVE THE RIGHT TO WRITTEN NOTICE WHICH IS TIMELY AND CONTAINS SUFFICIENT DETAIL, INCLUDING THE BASIS OF THE CLAIMS.PARTIES SHALL BE ALLOWED TO BE REPRESENTED BY INDEPENDENT LEGAL COUNSEL, AND PROCEDURES SHALL NOT IMPOSE OVERLY BURDENSOME REQUIREMENTS CONCERNING MANDATORY PERSONAL APPEARANCES. ALL PARTIES TO SUCH PROCEDURES SHALL BE DULY ENTITLED TO SUBSTANTIATE THEIR CLAIMS AND TO PRESENT ALL RELEVANT EVIDENCE. THE PROCEDURE SHALL PROVIDE A MEANS TO IDENTIFY AND PROTECT CONFIDENTIAL INFORMATION, UNLESS THIS WOULD BE CONTRARY TO EXISTING CONSTITUTIONAL REQUIREMENTS.

(18) National Security

: NATIONAL SECURITY IS DEFINED IN THE NATIONAL SECURITY LAW AS THE STATUS WHERE THE POLITICAL POWER OF THE STATE, SOVEREIGNTY, UNITY AND TERRITORIAL INTEGRITY, PEOPLE'S WELL-BEING, SUSTAINABLE DEVELOPMENT OF THE ECONOMY AND SOCIETY, AND OTHER SIGNIFICANT INTERESTS OF THE STATE ARE RELATIVELY FREE FROM DANGER AND THREATS WITHIN AND OUTSIDE THE STATE, AND THE COUNTRY'S CAPABILITY FOR SAFEGUARDING CONTINUED SECURITY. . 
The National Security Law also identifies several key sectors to the national economy to be protected by the National Security Review regime, including include finance, resources and energy, food safety, culture, technology, internet and cybersecurity, ecological and environment protection, nuclear power and nuclear technology and the exploration and use of outer space, international seabed areas and polar regions.

(19) Royalty: „A royalty is a legally-binding payment made to an individual, for the ongoing use of his or her originally-created assets, including copyrighted works, franchises and natural resources."

(20) Foreign Investment Security Review System: The existing regulations relating to national security review are the Notice on Establishing a Security Review System for Foreign Investors' Mergers and Acquisitions of Domestic Enterprises (NSR Notice) released by the General Office of the State Council in 2011 and the Regulations on Implementing the Security Review System for Foreign Investors' Mergers and Acquisitions of Domestic Enterprises (NSR Provisions) released by MOFCOM . Also, since there is only Article 35 of FIL as a principle provision to address the security review, the specific content of the security review system remains to be stipulated by the State Council.

The scope of National Security System set out by the NSR Notice and the NSR Provisions apply to elements that (1) Military industry enterprises and military industry support enterprises; (2) Enterprises near key and sensitive military facilities; (3) Any business related to national defense security; or (4) Any of the following enterprises related to national security where the foreign investor may obtain actual control of the enterprise after the acquisition: (a) important agricultural products; (b) important energy and resources; (c) important infrastructure; (d) important transport services; or (e) key technology and manufacture of major equipment. 
(21) The Credit Information System: The Corporate Social Credit System (CSCS) allows to monitor enterprise own credit score in order to take appropriate credit restoration or complaint action in a timely manner. Different platforms are aimed to serve the credit data to the general public at the national level: the National Enterprise Credit Information Publicly System (NECIPS), the CreditChina website and the "National "internet + Monitoring" System" (NIMS). NECIPS is the reference platform for basic company information (such as IP dispossession records, trademark registration, etc), administrative certifications, administrative penalties, operational irregularities (watchlist), and list of untrustworthy entities (Blacklist). Credit China is the user-friendly research tool on SCS records, and NIMS monitors the social credit systems .

(22) Divulging National Secrets: Refer to the State Secrets Law (revised in 2010), „for the purpose of "protecting state secrets, safeguarding state security and national interests and ensuring the smooth progress of reform, of opening to the outside world, and of socialist construction." (Article 1). Information is not to be considered as a "state secret" unless it is determined to be a state secret in accordance with legally defined procedures, and knowledge of it is restricted to a defined scope of personnel for a defined length of time .

„Disclosing, leaking, or divulging state secrets“ includes allowing a state secret to be known by any individual that is not allowed to know such information; or allowing information to go beyond the specified group of individuals allowed access to that secret, while not be able to prove that such a disclosure of information did not take place.

(23) Seriousness of infringement: There are three types of sanctions in China, criminal, administrative (when it is not deemed serious enough to warrant criminal punishment) and Party sanctions for Party members . 
: AN ACT OR PARTICULAR BEHAVIOUR WAS CONSIDERED A CRIME BASED ON THREE MAIN FACTORS: THE NATURE OF THE CRIME (AS DEFINED BY THE SERIOUSNESS OF THE ACT), THE AMOUNT OF DAMAGE CAUSED BY THE ACT AND THE STATE OF MIND OF THE OFFENDER. THE INTERPRETATION OF THE "SERIOUSNESS““ OF THE ACT WHICH DETERMINED WHETHER THE ACT IS A CRIME OR A MISDEMEANOUR, ALTERED FROM ONE POLITICAL PERIOD TO ANOTHER .

(24) Eight Categories of Abnormal Application in Trademark Law: Article 3 of „Rules to Strengthen the Administration of Trademark Application Activities (Draft for Comments)“ includes (1) applying for registration of a trademark that is familiar to the relevant public; (2) that has been used by others and that has obtained a certain influence (3)same of similar to that of another, when one knows or should have known of the existence of other's prior rights (4) with obvious improper purposes (5)a large number of trademark applications within a short time (6) without a genuine intention to use or an actual need (7)engage in other acts such as violates the principles of honesty and good faith, infringe upon others' rights and interests (8)helping others or trademark agencies with the mentioned actions in (1)-(7) .

(25) Prima Facie evidence: The specific evidence that supports a case or an element that needs to be proved in the case.

Annex 3: Background Conceptual Framework

The legal framework of IPR laws in China is formed overwhelmingly by the Chinese political framework and differs fundamentally from IP law in western countries. There have been three distinct bodies of IPRs protections for FDI exist 
simultaneously in China: the Chinese law, international investment law-mostly through BITs-and WTO protections under TRIPs .

The Chinese laws relevant to IPR are regulated by the National Intellectual Property Administration (CNIPA), which is governed by the State Administration for Market Regulation (SAMR) set up by the National Peoples' Congress (NPC) in March 2018. Specifically, the Patent Law (amended in 2008) grants a legal right to patentees for their creations, including inventions, utility models, and designs; the Trademark Law (amended in 2019) approved and registered by Trademark Office (TMO) of the CIPO gives registrants an exclusive right to use the trademarks; the Copyright Law (amended in 2010) regulated by PRC National Copyright of Administration (NCAC) for nation-wide copyright registration and Copyright Protection Centre of China (CPCC) for computer software. NCAC and CPCC jointly protect the authors' copyright in their literary, artistic, and scientific works . In addition, any technical information or business operation information which is unknown to the public and has a commercial value, and about which the owner has taken secret-keeping measures is therefore considered as "trade secret" and is protected by Anti-Unfair Competition Law (amended in 2019) and Administrative Licensing Law (amended in 2019), both regulated by SAMR . In particular, the Licensing Law is involved with granting to another party the exclusive rights of a patent by the patent owner on agreed terms and conditions for the transfer of technology .

At the international level, protections of IPRs consist of different international agreements, for most the Agreement on TRIPs administered by WTO and a growing number of BITs with IP provisions . For WTO members, their legislations and enforcements are expected to meet the TRIPs standards. The compositions of TRIPs include domestic procedures, remedies for the enforcement of IPRs, and dispute settlement. The obligations of the TRIPS apply equally to all Member countries, but developing countries are given a longer period to implement them in . 
Meanwhile, BITs usually take the form of free trade agreements (FTAs), to discuss its additional standards (known as TRIPS-plus provisions) with a significant political dimension. BITs, include definitions of investors and investments, the scope and place of application, with a combination of relative and absolute standards for treatment of foreign investors and their investments. The relative standards make comparisons between the treatment of the foreign investors and the host state's own nationals via national treatment, or by comparing the treatment offered to other nation's via most-favour nation (MFN) treatment clauses. In contrast, the absolute standards are independent treatment from those provided to any other domestic or foreign investors and investors can rely upon absolutely, such as fair and equitable treatment (FET) and other minimum treatment requirements. BITs were developed for the protection of investment generally without particular focus on IPRs, and as such, the enforcement of higher standards for IPR is usually done under IIAs . IIAs (International Investment Agreements), one form of the BITs and FTAs, are agreements concluded between States for the promotion and protection of reciprocal investments, such agreements usually protect IP by including it in the definition of investment .

A) Status of international law in the constitutional order of China

Generally, there are two theoretical approaches to the relationships between international law and municipal law: the monist approach which international law is part of domestic law, or the dualist approach in which the international law and municipal law exist separately. Nonetheless, there is also a third approach that attempts to modify the dualist position by "denying that any common field of operation exists as between international law and municipal law by which one system is superior or inferior to the other" . In Chinese legal practice, the majority of the Chinese scholars tend to adopt the third approach since the Chinese Constitution has no express provision on the relative status of international treaties and laws to municipal law. The reflection of the Chinese position on the 
implementation of international law is provided in Article 142 of the 1986 General Principles of Civil Law

: IF ANY INTERNATIONAL TREATY CONCLUDED OR ACCEDED TO BY THE PEOPLE'S REPUBLIC OF CHINA CONTAINS PROVISIONS DIFFERING FROM THOSE IN THE CIVIL LAWS OF THE PEOPLE'S REPUBLIC OF CHINA, THE PROVISIONS OF THE INTERNATIONAL TREATY SHALL APPLY, UNLESS THE PROVISIONS ARE ONES ON WHICH THE PEOPLE'S REPUBLIC OF CHINA HAS ANNOUNCED RESERVATIONS. INTERNATIONAL PRACTICE MAY BE APPLIED TO MATTERS FOR WHICH NEITHER THE LAW OF THE PEOPLE'S REPUBLIC OF CHINA NOR ANY INTERNATIONAL TREATY CONCLUDED OR ACCEDED TO BY THE PEOPLE'S REPUBLIC OF CHINA HAS ANY PROVISIONS.

It could be interpreted that an international treaty is superior to municipal law when applicable law could not be found in either Chinese law or any treaty concluded or acceded to by China.

B) The constitutional structure of IPRs in China

The NPC is defined in the 1982 Constitution as the "highest organ of state power" under the leadership of Communist Party of China. The main functions are to amend the state constitution and enact laws, supervise the enforcement of the state constitution and the law, elect the major officials of government, etc. The Standing Committee of the NPC interprets the State Constitution and laws, helps to supervise the work of the executive and judicial organs, approves or removes senior judicial officials, etc. The NPC and its Standing Committee have the ultimate authority to interpret law and to enforce the Constitution. The State Council executes laws, drafts and implements regulations, supervises the government bureaucracy and thus carries out the administrative functions of the Chinese government (the 
constitutional structure is illustrated below). The Chinese Constitution directs the State Council to assure the laws passed by NPC are promptly and properly executed. Under the State Council, it includes Ministries, Commissions, and the working organs of the State Council. The local organs „at and above the county level direct the works, and have the power to alter or annul inappropriate decisions of their subordinate departments and of the people's governments at lower levels". As such, the local organs are given considerable decision-making authorities but are vulnerable to changes in direction and decisions originated at the central level of government.

Linking to IPRs, its laws are therefore enacted by the NPC and its Standing Committee, its executive regulations are issued by the State Council (at times, collaborations across different ministries and State organs), and its local regulations are issued by local People's Congress. The hierarchy orders of the Chinese legal system make sure that executive regulations, for example, cannot contravene laws promulgated by the NPC .

With the contexts provided above, there would be all together four bodies of laws I would discuss in this thesis on IPR protections, namely, the Chinese laws, TRIPs and BITs (international investment laws), and Phase 1 trade deal. Their interrelationships are demonstrated in Diagram 1.

Furthermore, relevant legal documents on Chinese IPR protection used in this thesis could be seen in Diagram 2.

C) Interactions of Different International Investment Laws (TRIPs and BITs) on China's IPR Protections 
TRIPs aims to provide a predictable and regulatory environment for international trade and to reduce the barriers and trade-distorting policies in Member countries . As a general principle of TRIPs, every member of the WTO expects to receive the benefits of the WTO system's primary tenets: (1) the National Treatment Principle , (2) the Most Favored Nation Principle (MFN) , (3) reciprocal tariff concessions ; and (4) prohibition on quantitative restrictions. TRIPs sets down the minimum standards for dealing with various concepts of IP. For the Signatories, they are bound by a network of shared international obligations, readily incorporated in their respective legislation. It is the most comprehensive multilateral agreement on IP to date.

In its WTO accession agreement, China committed to eliminate (i) national treatment and market access restrictions on foreign enterprises, and to enable these services through a local presence within three years of China's accession. However in practices, China had continued to impose on market access limitations on wholly foreign-owned enterprises and in a number of services and goods, such as media, wholesaling services, franchising services, retailing services, processed oil, etc . (ii) in terms of tariffs and quantitative restrictions, the Chinese government has attempted throughout the years to lower import tariffs and quantitive restraints. In addition, special trade zones establishment in China also provides exceptions to the usual customs procedures and allow for preferential tariff and tax treatment. It is, however, still observed by the 2019 USTR report on China's WTO compliance that, China had continued to deploy a combination of export restraints, including export quotas, and other restrictions on a number of raw material inputs where it holds the leverage of being among the world's leading producers. Further consistencies with the WTO general principles of Chinese laws, in the light of Phase 1 Agreement would be discussed in the evaluation section. 
On the other hand, the proliferation of BITs is seen as a more frequent and robust IPR provision than TRIPs . It is often expressed as „TRIPs Plus“ Agreement . Currently, there are 145 BITs signed with China. The coverages of BITs normally include various treatment standards on IPRs, e.g. national treatment mostly, MFN, treatment according to the highest international standard and fair and equitable treatment (FET), also the dispute settlement mechanisms.

Similarly, both BITs and TRIPS Agreement aspire the market based transfer model which encourages FDI to profit from its technology transfer by putting developing countries' companies in fair competition with industrialised countries. However, the approaches of BITs and TRIPs could be different in nature. Firstly, with regard to IP conventions, the TRIPs provide for MFN treatment instead of National Treatment so as to emphasis the intention of WTO Members to integrate IP firmly into the multilateral trading system by setting a "common floor“. Secondly, the TRIPs Agreement is more suitable dealing with international level with a state-centric approach, while BIT is more advantageous on the rights of individual investors. For examples, the WTO's DSU provides for a state-centric despite resolution approach, with no access for private parties possible. The WTO DSU involves with „a cessation of the unlawful act, compensation on a state-to-state level, or...for a withdrawal of concessions by on sides of the damaged party." . BITs, however, centres on the rights of individual investors by offering financial relief or reparation for the losses suffered from the host state, which also means that the sovereign immunity of the state is waived. As such, BITs could be seen as a new enforcement instrument, especially being advantageous for foreign companies compared to any multilateral or bilateral agreement providing only for state-to-state dispute.

On the flip side, one of the biggest concerns in IPRs protection is IPR piracy, which is often large-scale and systematic infringement on IPRs. It typically involves with trademarks and copyrights, but also with patents systematically abused to appeal to 
the benefit of the host country's companies. To systematically mitigate piracy, BITs would need to add with a whole range of protection clauses, whereas TRIPs would deal with the role of governments in protection international IPRs within one framework to make them obligatory on the international level as an international minimum standard, and binding to WTO Members as a mandatory part of their international trading system .

The question arises of if TRIPs could override exceptions to certain rights as specified in a particular BIT and thus altering the scope of rights related to IPRs . It could be argued that TRIPS Agreement, especially if the host state is a WTO Member and the fact that TRIPS standards are known to form the floor of international IPR protection levels, it is therefore also an expectation of an investor that, TRIPs should therefore be the international minimum standard with a range of bilateral and regional agreements building on it. While BITs are not limited to any TRIPs standards and the extent of TRIPs being directly transferable to BITs context could be still open for discussion. BITs would therefore be particularly relevant for non-WTO Members and the provisions of BITs could increase the overall recognition of IPRs on the international level by implementing decentralised legal and administrative framework of States' domestic systems .

D) WTO Cases and Its Dispute Mechanism Involving US and China Trade War In the wake of 2018, the start of the US-China trade war was based on its Section 301 of the Trade Act of 1974, which applies if a foreign country denies the United States its rights under FTAs or carries out practices that are unjustifiable, unreasonable or discriminatory, including tariffs and quotas. Correspondingly, China has retaliated against US using Article 47 of China's Foreign Trade Law (2004) . Although given the fact that both parties have actually filed WTO complaint cases , they have neglected the remedial framework of WTO. Specifics of US-China trade war could be seen in Diagram 3. 
Regardless of the outcome by the Dispute Settlement Body (DSB) in this trade war, there are clearly deficiencies in the formation of WTO DSM. The sole aim of DSM is to bring a member's inconsistent measure into consistency with the WTO rules within a period of reasonable time, which could take more than three years depending on when the losing party decides to comply with the DSB ruling . The structure of DSM is that if a complaint has been accepted, the Appellate Body would be most likely to recommend to "bring the [non-conforming] measure into conformity“ with the relevant WTO Agreement. If the complainant member considers the measures taken by the member concerned is non-satisfactory, it could bring a dispute under the Article 21.5 of DSU, the so-called „compliance panel“ . If none of the procedures works out, the „suspension of concessions“ for retaliatory trade sanctions by the affected member state, could only be used with authorisation by the DSB and it must be at a level „equivalent to the level of nullification or impairment" caused by the non-compliance. For further remedial measure, WTO only provides for the winning party aiming to induce the losing party into consistency. The option of a negotiated compensation could be brought up with the consent of the losing party, without covering the period preceding the ruling of the DSB. The compensation is only subjected from the time the panel ruling is adopted by the DSB to the time of the losing party's compliance. The effect is that the complainant whose benefits have been nullified or impaired continues to suffer economic loss until full compliance is achieved .

It can be said that the usage of DSM have indeed provided some indirect benefits to Member states, such as mollification of domestic anxiety, encouraging a more cooperative international trading environment, and in this trade war case, China could use DSB recommendations to speed up the reforms domestically. However, the WTO DSM is not an effective legal system with its ruling on a "negative consensus“ basis, taking long periods of time for decision-making by the DSB, and 
lacks monetary compensation. In practice, the DSM has been taken advantage by many countries while the complainants usually suffer great economic loss until the accused State voluntarily conforms to the WTO framework. As such, this paper argues that Phase 1 Trade Agreement in this scenario, is the most effective solution to consider the expectations of vulnerable private entities in a multilateral dispute settlement. It lays most of mandatory implementation burden on China and takes effect within 30 days of signatures by both Parties. Phase 1 Trade Agreement could thus be considered as a unilateral act of protectionism, which WTO ultimately wishes to prevent. From a realist's perspective, such agreement is a manifestation of political confrontations, without the constraint of an international organisation to channel the behaviour of the States. It acts with pure self-interested motives .

This page intentionally left blank.

I. Introduction

Intellectual property right (IPR) is an important property right and the IPR protection system is an important legal system, which helps to secure economic rights from legal rights and effectively protects and stimulate $s$ knowledge creation and technical innovation. IPR protection is also a longstanding, critical concern for foreign companies in China. IPR is consistently placed among the top issues raised by the US concerning a range of unfair conducts, such as the technology transfer requirements imposed as a condition to access the Chinese market. China on its part has been developing relatively rapidly in the intellectual property protection as a response to the U.S.-China trade war in various aspects such as law, enterprise and society. The new launch of Chinese Foreign Investment Law (FIL) in January 2020, for example, is one of the unusual legislative responses pushed forward under Xi Jinping's leadership to protect the legitimate interests of foreign investors in China. Unimpeded by the outbreak of COVID-19, China commits itself to implement Phase 1 agreement further, by launching „Iron Fist“ and „Further Action Plan“ in May 2020. 
As such, one could observe that the influence of U.S.-China bilateral relationship have played important roles in both the formulation and implementation stage of the law.

With the recent rapid improvements in its IPR protection for the rights of foreign direct investment (FDI), China has also improved its core competitiveness in the international order. One could see the legal steps China is taking currently to be more recognised in the international community by honouring international rules and fulfilling its international commitments to embrace a new open economy. It is found that the higher the level of IP protection in developing countries is, the more the U.S. invests in them and more attractive to the US. Recent researches have proven to show a positive relationship between the quality of formal legal arrangements of IPR systems with FDI inflows. For a developing country like China, increasing FDI could promote a country's economic growth. It is therefore expected the improved IPR protection system in China as a result of Phase 1 Agreement could enhance closer trade cooperation and its bilateral relation especially with the United States.

\section{Methodology}

This thesis focuses on the formal legal aspects of IPRs protections in China. The formal legal aspects concern with the legislations that deliver laws, and confers rights, obligations and regulatory requirements, whereas the informal legal aspects concern with the behaviour of agents involved in enforcing the legal rights which will not be discussed in this thesis. The interest of this thesis lies in how are IPR-related FDI protections available under Chinese domestic law with the introduction of the Phase 1 Agreement. 


\section{JOSHA}

Journal of Science, Humanities and Arts

The structure of the research would be conducting a doctrinal legal analysis deals with legal theories, existing laws, regulations and authoritative materials analytically on this specific matter of IPRs protection. Specifically, it would compare and contrast the relationships between different bodies of law, and raise potential unclarity or conflicts out of these current simultaneous protections of law. Since IPRs especially under the Phase 1 Agreement concerns with various commercial sectors, the analysis of this paper would also give some focus on the legal effects of IPR on different industries. The paper mainly argues, the US and China may have been presented to resort to unilateral measures due to the deficiencies in the dispute settlement mechanism of the WTO, and the Phase 1 Trade Agreement has direct and effective influences on the current IPR protection in China. The thesis, thereafter conducts legal doctrinal analysis on the Chinese laws, Phase 1 Agreement, and comparisons between these two bodies of law. The goal of this research is to analyse the current legal standards of IPR protection for foreign companies in China, which is relevant to the two powers' overall economic relations and longtime discussions in response to the recent event of the U.S.-China trade war. It is a hope that the paper could contribute to one part of the dynamic changes involved with the inflows of FDI in the development of Chinese investments.

When discussing IPRs in this thesis, it is important to notice that the Articles in Chinese laws do not address a specific State Organ, but often refer as "the State“ due to its decision-making authority that a law must be adopted by the Standing Committee of the NPC and promulgated by the President. Also, due to the limited space available, expanded definitions on several legal concepts would be clarified in Annex 2, and descriptions on the relationships among four bodies of laws related to IPRs protections in China, and the US-China Trade War in relation to the drawbacks in the WTO dispute settlement mechanism and its remedial conundrum would be clarified in Annex 3. 


\section{Existing Academic Literature}

Currently, there is a lack of academic literature covering a detailed doctrinal legal analysis on FDI protections on IPRs. The legal effects of the adopted new legislations have not been studied extensively other than reported in the scattered law blogs. For example, El-Mohtar, in this respect, has concrete but brief legal analysis on how bodies of the Chinese law, BITs and TRIPs interact with each other. Also, Mark Cohen, has followed up the Chinese laws closely with a series of brief analysis. These informative blogs, although brief, can be found referred frequently in this thesis.

The existing journals are useful in analysing the background information of the Chinese law structures and the US-China trade conflict, protection of IPRs in the international investment law and its relation to the Chinese laws, as well as providing the past IPRs protection in China so that it could be utilised for references in this thesis. For examples, $\mathrm{Li}$ and Castellucci address the political considerations of China and its dependance of judicial system on the Party control is an integral part of IP policies in the ongoing US-China trade war. Particularly, the USTR reports on China have given a comprehensive overview on China's incoherence with the WTO standards, and addressed extensively on the issue of lack of IPRs protections.

Some of the books have discussed over a few particular laws or aspects of China, which facilitate the understandings of the Chinese law system under its socialist construct. One typical example provided by Cheng Bian, is involved with the Chinese State Secret law, which although has not been amended yet, forms the legitimate basis for the restrictive and prohibitive investments for foreign investors. 
Further, Esther Lam has made it also important for the readers to acknowledge the Chinese law context, as its rule of law could be fundamentally different from that of Western societies.

Besides, there also has not been enough attention given on the legal changes on smaller scales. This thesis would therefore also discuss in detail of the newly amended changes in the Chinese administrative processes, legal liabilities, and sectoral restrictions, with diagram illustrations.

IV. The impact of US-China trade war

Since the US and China do not have a BIT, the difficulties of finding an appropriate legal basis for accusations such as claims another party's state-backed outbound acquisitions of technologies could partially explain why the US felt the necessity to engage in a trade war, instead of resolving in the existing international institutions. According to Section 301 Report on the Chinese law itself, which includes:

A)Unfair technological transfer: The Chinese regulations such as Special Administrative Measures (Negative List) for the Access of Foreign Investment requires restrictions for foreign companies investing in certain industries with only through cooperative agreements with their Chinese partners.

B) A range of other coercive regulations of discriminatory restrictions appear in the Regulations of the People's Republic of China on the Administration of the Import and Export of Technologies ("TIER 2011") and the Regulations for the Implementation of the Law of the PRC on Chinese Foreign Equity Joint Ventures ("JV Regulations 2014") . The discriminatory restrictions often made on the basis of nationality, including measures that inflict damage on the investors without serving any apparent legitimate purpose, not based on legal standards but on discretion and 
prejudice, taken for reasons that are different from those set by the decision-maker, or taken in wilful disregard of due process and proper procedure .

C) The U.S. claimed the Chinese government has supported "cyber theft" into the commercial networks of US companies. Under WTO DSU, the United States has reported to the WTO Dispute Settlement Body on 23 March 2018, under the WTO dispute settlement case (DS542), stating that China on the protections of IPRs are inconsistent with obligations of TRIPs Article 3(1) (national treatment) by giving enhanced rights to the Chinese party the right to continue to use technology transferred under the agreement after its expiration and TRIPs Article 28 (rights conferred) of forced technology transfer of foreign patent owners .

Nonetheless, in the light of the US-China trade war, both countries have taken unilateral retaliatory measures and gone beyond the rules of WTO . The DSU prohibits the concept of self-help by WTO members who resort to unilateral measures in disputes for which WTO dispute settlement is available. Specifically, DSU Article 23.1 requires all WTO members to follow the procedures of the DSU when they seek redress of alleged violations of WTO obligations. DSU Article 23.2(a) explicitly prohibits a WTO member from unilaterally determining that: (1) a violation of WTO obligations has occurred; (2) other commercial benefits have been denied (in non-violation cases); or (3) that the attainment of any objective of the covered agreements has been impeded. The second and third categories provide scope for interpretation to enlarge the prohibition against self-help significantly.

As result, Phase one Trade Agreement between China and US was signed on 15 January 2020 . Correspondingly, new 2019 amendments of the TIER, Trademark Law, Anti-Unfair Competition Law, and Administrative License Law were passed at an extraordinary speed in China. The draft amendment of Patent Law in 2019 has yet released its final document. Further, it can also be observed in the 2019 released 
edition of Special Administrative Measures on Access to Foreign Investment (National Negative List), the Free Trade Zone Special Administrative Measures on Access to Foreign Investment (FTZ Negative List), and the Catalogue of Encouraged Industries for Foreign Investment (Encouraged Catalogue) for the foreign ownership restrictions. In addition, there are also new regulations formed: (1) FIL that came into force on January 1,2020 , replaces previous three main foreign investment laws to protect the trade secrets of foreign investors from being disclosed by government officers, and to address the legal liabilities for violations to welcome new foreign investments (2) Regulation for Implementing the Foreign Investment Law of the PRC came effective on 1 January 2020, and (3) „Iron fist“ plan and another further action plan to implement national IPR in May 2020.

\section{Chinese Law}

FIL was approved by the National People's Congress of PRC (the „NPC“) at the second session of the 13th NPC on March 15, 2019, and it came into force on January 1,2020 . It replaces the three existing laws on foreign investments in China (the "Three FDI Laws"), namely the Law on Sino-Foreign Equity Joint Ventures (the „JV Law"), the Law on Sino-Foreign Contractual Joint Ventures (the "CJV Law") and the Law on Wholly Foreign Owned Enterprises) and become a fundamental law of China in the foreign investment area. For FIEs (Foreign Invested Enterprises) established prior to the implementation of FIL, it is given up to five years of transitional period, during which these FIEs may continue to retain their existing organisational form and bylaws .

Consistent with its position under the FIL to protect foreign investors' legitimate rights, on 18 March 2019, the State Council of China released the Administrative Order No.709 announced amendments to its intellectual property legislations with immediate effect. The Trademark Law was amended for more stringent civil liabilities for IP infringement. According to Article 58 of Trademark Law, when a registered 
trademark or an unregistered well-known trademark is infringed and misleads the public, it shall be also dealt with the Anti-unfair Competition Law of the PRC. The functions of TIER aim to regulate and maintain the order of technology import and export, through ways of trade, investment, and economic and technical cooperation, in order to enhance the Chinese national economic growth and social development. The acts of the technology import and export include assignment of the patent right, assignment of the patent application right, licensing for patent exploitation, assignment of technical secrets, technical services and transfer of technology by other means . Namely, the Competent Department of Foreign Trade and Economic Cooperation (the Competent Foreign Trade Department) under the State Council is in charge of national administration of technology import and export in accordance with the Foreign Trade Law. This department, in conjunction with other relevant departments under the State Council, formulates and publishes restricted or prohibited catalogues. Consequently, on 30 July 2019, National Negative List, FTZ Negative List, and the Encouraged Catalogue came into effect. Therefore, entry into the Chinese market is regulated by the country's negative lists and encouraged catalogue for foreign investment, so as to specify prohibited sectors and sectors that are open to foreign investors, respectively. In industries that are neither prohibited or restricted, foreign investors are expected to be treated equally as well as domestic investors. FIL shall be considered in conjunction with negative lists and encouraged catalogue, which would involve administration of the negative lists, reporting requirements for foreign investment projects and national security review procedures.

Covered by Article 2 of FIL, there are four specific channels for conducting foreign investment:

(i) forming new FIEs;

(ii) investing in existing enterprises through mergers and acquisitions;

(iii) investing in new projects; 


\section{JOSHA}

Journal of Science, Humanities and Arts

(iv) other approaches stipulated under laws, administrative regulations or promulgations of the State Council;

FIL states that country wants to open to the outside world and encourages foreign investors to invest in China. According to Article 3 of FIL, it also ensures to have a reformed policy system which is stable, transparent, predictable and fair market environment, which cohere with the „fair and equitable treaty“(FET) as the international minimum standard under the customary international law. In this section of analysis, it will evaluate to what extent the Chinese laws comply with the elements of FET principle.

Specifically, the international arbitration tribunal (ICSID) has outlined two definitions on the fair and equitable treatment clause, which are:

(I) : [FET] REQUIRES THE CONTRACTING PARTIES TO PROVIDE TO INTERNATIONAL INVESTMENTS TREATMENT THAT DOES NOT AFFECT THE BASIC EXPECTATIONS THAT WERE TAKEN INTO ACCOUNT BY THE FOREIGN INVESTOR TO MAKE THE INVESTMENT. THE FOREIGN INVESTOR EXPECTS THE HOST STATE TO ACT IN A CONSISTENT MANNER, FREE FROM AMBIGUITY AND TOTALLY TRANSPARENTLY IN ITS RELATIONS WITH THE FOREIGN INVESTOR, SO THAT IT MAY KNOW BEFOREHAND ANY AND ALL RULES AND REGULATIONS THAT WILL GOVERN ITS INVESTMENTS, AS WELL AS THE GOALS OF THE RELEVANT POLICIES AND ADMINISTRATIVE PRACTICES OR DIRECTIVES, TO BE ABLE TO PLAN ITS INVESTMENT AND COMPLY WITH SUCH REGULATIONS.

(II) [FET STANDARD] IS INFRINGED BY CONDUCT ATTRIBUTABLE TO THE STATE AND HARMFUL TO THE CLAIMANT IF THE CONDUCT IS ARBITRARY, GROSSLY UNFAIR, UNJUST OR IDIOSYNCRATIC, IS DISCRIMINATORY AND EXPOSES THE CLAIMANT TO SECTIONAL OR RACIAL PREJUDICE, OR INVOLVES 
A LACK OF DUE PROCESS LEADING TO AN OUTCOME WHICH OFFENDS JUDICIAL PROPRIETY - AS MIGHT BE THE CASE WITH A MANIFEST FAILURE OF NATURAL JUSTICE IN JUDICIAL PROCEEDINGS OR A COMPLETE LACK OF TRANSPARENCY AND CANDOUR IN AN ADMINISTRATIVE PROCESS. IN APPLYING THIS STANDARD IT IS RELEVANT THAT THE TREATMENT IS IN BREACH OF REPRESENTATIONS MADE BY THE HOST STATE WHICH WERE REASONABLY RELIED ON BY THE CLAIMANT.

As seen, there are eight principles as elements of fair and equitable treatment that often referred in international arbitral tribunals, in applications of the Chinese laws, these principles are specifically:

(1)The requirement of stability, predicability and consistency of the legal framework:

The Chinese laws have promised "the State shall protect the intellectual property rights of foreign investors and foreign-invested enterprises, protect the legitimate rights and interests of intellectual property rights holders and related rights holders, and pursue legal liability for intellectual property rights infringements in strict accordance with the law." As a result, any trademark infringement damages, transfer fees or trademark royalties shall be refunded fully or partially. Further, if a trademark registrant or an interested party has evidence that another party is committing or is soon to commit an act that infringed upon the party's exclusive right, and will cause irreparable damage to its legitimate rights and interests, the party could apply to the people's court for an injunction and taking asset preservation before filing a lawsuit. From these standardised legal expectations, the compensation schemes from trademark infringements would be more predictable, and FIEs would be more encouraged to undertake investments in China. 
In terms of operational measures, „the State encourages, supports, and protects public scrutiny, from all organisations and individuals, of acts of unfair competition.... Industry organisations shall strengthen industry self-regulation.“ . The State Council would also establish a coordination mechanism of anti-unfair competition work to research and decide major policies, so as to maintain the order of market competition. Noticeably, the establishment of such coordination mechanism to facilitate competition policies is seen to reinforce the FIEs' expectations for the stability of the legal regime. In addition, the rules of electronic data used as evidence in IP cases have also significantly improved. The new provision in Evidence in Civil Procedure (the „New Evidence Provisions") came into effect on 1 May 2020 by the Supreme People's Court (SPC). It substitutes the traditional approach of securing the electronic data with two notary officers, which is often costly and time consuming, adding storage of evidence with electronic devices.

Although the actual operation of laws depend on other factual circumstances, it can be observed that China has increased its explicit promises or guaranties, in both its laws and IP enforcement policy, which could be considered as legitimate expectations or assurances that foreign investors could take into account. In exchange, it would mean that individuals and entities need to adapt their behaviours to the requirements of the legal order and thus form stable social and economic relationships .

(2) Protection of legitimate expectations

Legitimate expectations are that the investor can expect the host state to act transparently and consistently, and the law should not affect the basic expectations that are taken into account by investors to make the investments. At the same time, the law would also weigh the State's legitimate regulatory interest. 
For international protection of FIEs' legitimate expectations, the State would strengthen bilateral and multilateral cooperation mechanisms with other countries, international organisations (IOs) in the field of investment . Particularly, eligible investors involved in which free trade zone agreements and investment agreements signed between China and relevant countries, and international treaties to which China participates, would receive preferential opening-up measures. The trademark registration in China is in accordance with relevant agreements signed between the country which applicant belongs and PRC, or any international treaty to which both countries are parties, or on the basis of the principle of reciprocity .

To protect investors' expectations of their legal rights, Article 8 of FIL guarantees that workers of FIEs shall establish trade union organisations to safeguard the legitimate rights in accordance with the law. FIEs also are allowed to raise capital through public offering of stocks, corporate bonds and other securities. If local governments at various levels would need to amend policy commitments or contractual agreements, the changes must be accorded to the statutory authority, and compensate FIEs fairly as result of such changes. It can be seen that China has promised to grant a high-level investment liberalisation and facilitation policy, with the principles of convenience, efficiency, and transparency. For IPR protections, act of forging, mutilating, selling or buying technology import and export licenses shall be prosecuted for criminal liability. Counterfeiting or knowingly selling goods bearing counterfeit registered trademarks constitutes compensation of the losses of the infringed, as well as investigation for criminal responsibility . Legal liabilities by damaging to another person's rights and interests through unfair competition could refer to Annex 8. Legal Liabilities of violations of exclusive right to use a trademark could refer to Annex 9 .

For financial interests protections, all of foreign investors' capital contributions, including IP license fees could be freely remitted in RMB or foreign currency. Also, 
the amount of damages shall be firstly determined by the person's actual losses caused by infringement. Where it is difficult to determine, the amount of damages would be according to the benefits acquired by the infringer. Where it is difficult to determine either losses or benefits, reasonable multiples of the royalties would be compensated. This set-up of compensations would therefore protect investments where actual losses are difficult to determine.

Further, to protect FIEs' sensitive business information, administrative organs shall not disclose business secrets of foreign investors, the Competent Foreign Trade Department, other relevant departments shall keep confidential of any trade secret when performing their duties of technology import and export administration. Any violations act against the provisions would be criminally liable for the crime of divulging State secret or infringing trade secret under the Criminal Law. When act is not so serious, he shall be imposed with administrative penalty . Similarly, malpractices of members of administrative organs shall be criminally responsible if violated the criminal law .

A State organ works in trademark shall not „neglect his duty, abuse his power, and engage in malpractice for personal gain, violate the law in trademark registration, administration, and review, accept money or things of value from a party, or seek illegitimate interests.“. Members of import and export administration who abuses official power would be punished for criminal liability or administrative penalty according to the seriousness. Acts that violate the principle of good faith and infringes the legitimate right and interests of a principal, the trademark agency shall bear civil liabilities and be recorded in the credit files. Noticeably, China has a dual track system of enforcement of both the administrative process and the judicial process. The administrative process involves with the Complaint System reporting to Administrative Authorities and they have their powers to investigate and penalise acts of infringement. It is often considered for quick, low-cost infringement cases, 
but a relatively weak enforcement unavailable for all types of cases. The judicial process is to file a complaint to a judicial civil court . Further, administration department would also establish and improve an internal supervision system to supervise and inspect the State organ functionaries in charge of trademark registration and observe discipline . In addition, the administration procedures for trademark registration and restricted or freely imported (exported) technology could refer to the Annex 5, 6 and 7 respectively.

In exchange, FIEs shall ensure the technology imported is conducive to promoting the scientific and technologic progress in China, enhancing the development of foreign economic and technical cooperation, and safeguarding the economic and technical rights and interests of the country . In order to also protect the host state's interests, importing or exporting without approval or exceeding the scope is criminally liable for the crimes of smuggling, illegal business operation, or divulging national secrets or other crimes under the Criminal Law. If the case is not so serious , he shall be pursuant to the provision of the Customs Law, a warning would be issued, illegal income would be confiscated, and/or an additional fine of one to five times the illegal income would be imposed. Also, if investing in an area prohibited, FIEs shall cease the activities and dispose of assets. Any illegal income would be confiscated. If investment violates the general provisions of negative list, the violators shall bear the legal liabilities as well . In addition, any violations of laws by FIEs would be recorded into the credit information system .

There have been promised a great extent of intentional cooperations in protections of IPRs, and much clearer administrative orders in explicating the procedures especially in the application of trademarks and punitive fines against unfair competition and trademark infringements. Also, the laws have improved on the specific disciplinary actions received by administrative employees, and legal liabilities on disclosure of trade secrets. 
(3)The requirement of grant procedural and administrative due process and the prohibition of denial of justice

The customary international law recognises, the regulatory body should take necessary actions to enforce the laws and the public power derives its authority from a legal basis. Procedural and administrative due process should be applied equally to all individuals faced with a similar situation and in compliance with the principles of disclosure, equity and justice.

It is stated that the functionaries of State organs involved, such as in trademark administration shall be ,impartial in implementing the law, honest and self-disciplined, and devoted to their duties, and shall provide services with civility." . Also, the State would ensure governments at all levels to minimise redundant reporting burdens absent the basis of other laws and administrative regulations, such as interfering with the normal production and operation activities . In addition, any entity or individual has the right to report a suspected act to the supervisory inspection department. The department could take measures to investigate suspected acts of unfair competition or patent-related infringements, based on the evidence obtained, inquires the parties concerned, and investigates the circumstances related. It may conduct on-site inspection of the places where the suspected illegal act is committed, consult and duplicate the relevant documents and check the products related to the suspected illegal act, and seal or withhold the products that are proved to be counterfeits. The suspected business must faithfully provide materials .

These provisions have set the requirements that administrative members must be educated to observe proper legal procedures in the execution of administrative rules, in order to prevent from abusing their power and fairness be guaranteed for all involved. 
(4)The requirement of transparency

Transparency should be applied to all procedural aspects of administrative law. However, this obligation could be difficult to define its precise scope of application, and in the most cases, this principle is used where the host state fails to disclose importance information .

(5)The requirement of reasonable and proportionality

The element of reasonableness is outlined in Tecmed v. Mexico, "there must be a reasonable relationship of proportionality between the charge or weight imposed to the foreign investor and the aim sought to be realised by any expropriatory measure.T . Reasonableness is used to control the extent to which interferences of host state with foreign investments are permitted to find a violation of fair and equitable treatment. The element of reasonableness can also be incorporated into a proportionality test. Proportionality allows for balancing the interests of host state and foreign investors .

The attitude of Chinese government towards foreign investors is that the State Council would protect their best legitimate rights and interests in accordance with the law, as well as the investments and income. In reciprocity, foreign investors shall not conduct activities which would harm China's national security or the public interest . Also, FIEs would not be imposed levy or expropriated the investment, unless as deemed necessary for the public interest, which would be conducted with legal procedures with timely and reasonable measures. Although the restrictive areas of investment work against the foreign investors' interest, there are certain sensitivities of host government and local interest groups in the protection of against unexpected domestic changes, and such restrictions are exceptions to the reasonable regulatory legal framework. 
(6)The concept of good faith

In Tecmend v. Mexico, the tribunal stated that all State actions should not only comply to criteria related to the guidelines, but also the goals underlying such regulations. The foreign investors would expect the State to use the „legal instruments that govern the actions of the investor...in conformity with the function usually assigned to such instruments." The duty of good faith, is rather used as a collective for other principles incorporated within the fair and equitable treatment standard .

The application of good faith is extensive in the Trademark Law. In terms of registration procedural matters, the registration or trademark-related matters could be handled by its own or entrusted by a trademark agency. The entrusted agency must firstly be entrusted before registering and uphold the principle of good faith, keep confidential the principals' trade secrets. If the agency knows beforehand any appliances of bad-faith trademarks, infringe upon another person's existing rights, or without authorisation of the client, he must not register. For trademarks that applied in bad-faith with malicious intent, would be subjected to heavier punishment. Also, it is prohibited of translation of another person's well-known trademark not registered in China, which misleads the public and the interest of the owner of registered trademark is impaired. The factors taken to be considered as a „well-known“ trademark are investigated by the administrative department for industry and commerce, and decided by the trademark office.

It is noticed the concept of „bad-faith“ trademark is emphasised, the infringer would receive heavier punishment or joint liability if the trademark agency knowingly aids the infringer. As such, the duty of good faith is collectively applied in the intention of trademark registration, the obligation of an agency, as well as in consideration of the public interest. 
Further, a business shall not mislead a person believing one commodity has a particular connection with another, it also shall not bribe individuals in order to seek competitive edges or opportunities. Acquiring a Chinese domestic enterprise or consolidating of other businesses must comply with the Anti-Monopoly Law of PRC . In the area of online business operations, any act misleads the users, being incompatible with the online product or service, and sabotaging the normal operation could be deemed causing in bad faith. If a trade secret has been infringed upon, the right holder shall provide prima facie evidence that the alleged tortfeasor has a channel to obtain the secret or the trade secret has been disclosed or at risk of disclosure by the tortfeasor, or the trade secret is otherwise infringed upon by the alleged tortfeasor. The alleged tortfeasor shall likewise, prove that the trade secret is not as described in this Article . In the Competition Law of China, the principle of good faith is therefore enshrined in competing with other businesses through legal and fair measures, and inclining the burden of proof toward suspected infringer, so as to maintain the public order and good customs.

It is thus reflected through the amendments of the Trademark Law and the Competition Law, China endeavours to safeguard public interest and social interest through promotion of good-faith governance.

\section{(7)No coercion or pressure}

"Coercion" can be understood as a threat by someone who indicates that if his demand is rejected, he will make the recipient worse off, and usually in the form of some abrogation of the recipient's rights. Also, the concept of „pressure“ or „coercion“ is rather a subjective term which might include a range of measures or circumstances, and high degree of constraint or inducement. Therefore, the use of coercion should also be associated with other principles, such as non-discriminatory practice. Specifically, the State Council shall conduct technical cooperation based 
on the principle of fairness, and administrative means should not be used to force the transfer of technology .

\section{(8)Non-discrimination principle}

The principle of non-discrimination prohibits discrimination unless it is based on a legitimate public policy objective and which should not go beyond the principle of proportionality. In practical significance, it is that nationality is not a legitimate basis for host state conduct

Firstly of all, foreign investors could not engage as individual-operated, solely individual-owned enterprise investors or members of professional farmers collectives. Also, FIEs cannot be established in fields when stock ownership is required. Other specific industry restrictions related to IPR could refer to the list in Annex 3. It is to be noticed that in Article 4 of FIL states that the function of these editions of negative lists (and TIER) is to establish a pre-entry national treatment in which the investment standards are not lower than that of domestic investor and their investments. Excluding negative lists, the State would ensure equal national treatment to foreign investment. The changes made to the negative lists are significant as previously foreign investors cannot receive protections until passing a particular approval by the competent authorities. China has now shifted from „market admission“ to the approach of „market entry“ and it could be deemed consistent with the principles for promoting foreign investment enshrined in FIL to an extent. However, one could observe that sensitive investments involved with Chinese national security, especially with geology and mapping, legal services, national mandatory education, religion, scientific research in social science and humanities, stem cell or genetic technology, valuable Chinese raw materials, and media information, are still prohibited to foreign investments. Further, one should expect further implementations of rules or revisions to the existing laws to guide the 
further liberation of the market for foreign investors. Furthermore, the scope of restrictions for trademark registration is summarised in Annex 4.

In terms of equal treatment as domestic enterprise, FIL emphasises the policies of the state would support development of enterprises equally to foreign-invested enterprises as well, specifically, FIEs would receive on an equal footing in information disclosure and social supervision of the setting of standards. FIL also promises foreign investment licensing procedure shall be consistent with domestic investment. Further, the Implementation Regulation explicitly addresses that the government shall not obstruct or restrict the free access of FIEs to government procurement markets. The Competent Department has also removed the controversial restrictive provisions over ownership of the improved technology in the previous TIER. FIL also explicates that in situations where international provisions could be more preferential to the admission of foreign investors, international treaties and agreements acceded by the PRC shall take precedence. In the Negative List, it is also reinforced that the Free trade zone agreements and Investment agreements signed between China and relevant countries, and international treaties to which China participates have more preferential opening measures for eligible investors. In detail, the Implementation Regulation of FIL clarifies foreign investors are entitled to preferential treatment in public finance, taxation, finance and land use if they make investment in relevant encouraged industry. Also, FIEs are entitled to enjoy corresponding preferential policies for reinvestment, such as expanding their investment in China with their investment income in China. Also, a foreign applicant when applying within six months from the date he applies for registration of his trademark for the first time in a foreign country, again applies in China for registration of one and the same trademark, he would enjoy priority .

Supported with some evidences above, the Chinese laws to some extent have fulfilled the FET with some elements of being non-discriminatory, relatively 
transparent, and taking due account of the legitimate expectations of the foreign investors. In the implementation of domestic laws, the international standard of FET would have degree of discrepancies depending on the domestic contexts. In the Chinese context, it is being recognised as a state-driven decision-making economy, which would limit foreign competition and favours state-owned enterprises to some extent.

Vl. Aspects of IP Reforms Comparing the Current Chinese Laws and the Past

This section of the research would discuss the explicit changes in the Chinese domestic laws. For detailed comparisons, refer to Annex 12.

\section{A) TIER}

The past provisions could deter FIEs from transferring the technology into China due to fear that (i) they could not afford to pay those mandatory indemnity - which party should bear the burden if the licensee's right to the licensed technology is challenged by a third-party. (ii) Also, it was unclear if a licensor would be able to share in technology improvements developed by the licensee. (iii) The past TIER could not freely negotiate the allocation of FIE's market right with the prohibition of unreasonably restricting the export channels of the licensees.

With the removal of the three provisions, the effect is that FIEs can now stipulate the liability bearer and the scope of liability in technology transfer, also be able to share the attributions of the improved technological achievements on the basis of mutual benefit . Technology imports in the future are therefore expected to increase. As such, the revised TIER coheres with the overarching principle set in Article 22 of FIL for an open economy and the cooperations could thus be negotiated on the basis of fairness and equality. It is also to be noticed that the deletion of the three provisions does not mean the restrictive clauses can be arbitrarily articulated in the technology import, due to Article 329 of Contract Law provides „a technology contract that 
illegally monopolises technology, impairs technological progress or infringes upon the technological achievements of others will be rendered null and void." In an Interpretation published in 2004, the SPC applied Article 329 to prohibit non-reciprocal restrictions on the making of use of improvements, non-essential tying conditions, and unreasonable restrictions on quantity, price or sales channels of products or services .

\section{B) Trademark Law}

The main objective of amendments is to curb bad-faith trademarks, with an increased punitive damages against trademark agencies for facilitating bad faith filings and compliance by trademark agency. Particular attention should be paid to Article 4 on bad faith trademark "without intent to use" shall be refused in applications. As the Chinese trademark piracy typically applies in a large sum with the intention to sell , Article 4 can therefore also apply if it is without proper reasons. Although „bad-faith" is not defined, factors are set out by the „Several Provisions on the Regulation of Trademark Application and Registration Behaviour“ („Provisions“) issued by SAMR, including (1) the nature of trademarks, e.g. if the marks are identical or similar to others' well-known brands; (2) the applicant's industry and business status; (3) administrative and judicial decisions that have taken effect (4) the number, the categories designated for use, etc. Additionally, the draft rules for trademark application have further listed eight categories to be defined as an „abnormal application“.

Secondly, the examinations in violation of such Article are also strict, as objections could be raised at the initial examination stage, during the announcement period by brand owner or any other third party, or at the cancellation stage through invalidation proceedings. It could be considered a significant progress as the Article 4 not only empowers the trademark office to reject and to object trademarks made in bad faith, but also grants oppositions and third party the right to raise opposition 
and to file nullification application, even after such trademarks have been successfully registered. It can be seen that together with Article 4, Article 33 and Article 44 have increased its heavy administrative approach by strengthening its regulation, and are intended to unify the current practice by establishing a solid legal basis on malicious trademarks.

Further, under Article 19 that trademark agencies are forbidden to represent clients when they know, or ought to know, the trademark to be filed for clients fall under Article 4. And also, when such a registration is made by the trademark agency, an administrative penalty such as a warning or fine shall be imposed, and if a trademark lawsuit is filed in bad faith by the trademark agency, the People's Court shall imposed a penalty accordingly. This additional thus reinforces the management on trademark registrations applied in bad faith by increasing the liability and sanctions for trademark agencies.

\section{C) Competition Law}

The scope of infringers is widened as it also cover misappropriation by non-business operators, such as employees and former employees. The acts of infringement have also been broadened to include „cyber invasion“ and facilitating the trade secret infringement by tempting and helping others to others to violate confidentiality. It can be seen that stricter punishments are imposed on helpers, instigators and tempters which are deemed as infringers to be punished. Particularly, the definition of violation of trade secrets has been amended from "agreement" to „Confidential obligation“, which could help the right holders to provide proof in the future. Also, the amounts of compensation have also increased: (1) compensation for punitive damages with malicious intent, allowing plaintiffs to recover up to five times, (2) statutory compensation to RMB 5 million when loss cannot be determined. 
For a long time, the trade secret owner needed to file lawsuits as they often lacked evidences to prove (1) its information met the statutory requirements to qualify as a trade secret, (2) the information of the infringer is similar or substantially similar to its trade secret, (3) the infringer has adopted illegal means. The new amendment aims to address these issues reduce the rights holders' burden of proof and the owner is now only required to provide preliminary evidence on the protective measures it took, and to a reasonable extent, that its trade secret is infringed . In addition, if the trade secret holder has prima facie evidence to his right has been infringed, the burden of proof is now shifted to the suspected infringer.

\section{D) Patent Law (proposed)}

The amendments have been long going with at least 4 different versions published, the latest draft of the Patent Law was published by the NPC on 4 January 2019. Under the new proposal, there are several new and re-definitions from the previous patent law. Firstly, a rather broad anti-monopoly provision is added for the first time. Specifically, the scope of application of the principal of "good-faith“ is introduced as to not abuse patent rights to harm public interest and the legitimate right of others, or to exclude or restrict competition. Secondly, a design patent, which protects the visual appearance of a product, can only protects a complete product but not a portion of a product which cannot be sold or used independently. The effect of such change is that the key components do not equip the patent owner with rights to enforce against competitors who copy only a portion of the product's aesthetics.

Also, there are also several extensions and priority, firstly, if within 6 months an applicant first files an application for a design patent, and files for a patent for the same subject matter, the applicant may enjoy the right of priority. Secondly, to compensate for the time for review and approval of innovative drugs, extension is granted for the term of invention patent rights that are simultaneously applied for 
approval in China and aboard, with an extension not exceeding 5 years and in total up to 15 years. Thirdly, the time limit for taking legal action against patent right infringement is extended from 2 years to 3 years.

The particular exclusiveness of the draft Patent Law is that it specifically deals with the joint liability of network service providers for online patent infringement. Either the patentee or interested party shall notify, or the department in charge of patent enforcement shall order the service provider to take measures, such as deleting, disconnecting the link to the counterfeit patent product. Additionally, failing to act would result the online platforms to be jointly liable with the infringers for the enlarged part of the damage and the infringing network user. Compared to the previous draft, there is a limited liability. The joint liability would also be imposed when they "should have known" of the existence of infringement but did not take necessary measures. This could lower the evidence required for the right holders to prove the possibility of knowing. This notice-deletion system, however, imposes significant potential liabilities on the right holders as they would be subjected to civil liability if they send incorrect notices that cause harm to the operators on the platforms. And if the incorrect notices are sent out in bad faith, the right holders would pay double damages. This could thus act as a deterrence to the patent right holders.

This draft Patent Law would not be discussed further in details, but in general, it also corresponds to the overarching objectives of other formally passed laws, such as calculations punitive damages and statutory damage, reversed burden of proof, stronger power of administrative authorities in relation to investigation, and increased fines for infringement. 


\section{Implementing Action Plans}

The „Iron Fist“ and the „further plan“ released by CNIPA in May 2020 are more comprehensive and direct reflections of the Phase 1 Trade Agreement to remedy IP concerns with specific strategies. The „further plan“ lists 100 points to accomplish the goal of becoming an „IP Power Country“. However, these plans remain unclear how effective the strategies would be in practice. The strategic goals of China is by 2020, it would become a country with comparatively high level in terms of the creation, utilisation, protection and administration of IPRs, also raise a culture with public awareness of IP. In general, China would raise the quality and quantity of the self-relied and self-regulated IP system and effectively involves itself in international organisations. It is therefore expected in the next 5 years, a number of world-famous brands will emerge in China, as piracy and counterfeiting would be significantly reduced, the expense of IP protection will decrease and abuse of IP would be curbed.

It is planned that (1) laws and regulations such as the Patent Law, Trademark Law and Copyright Law would all be promptly revised, (2) IP policy suitable for relevant industries needs to be formulated to promote the optimisation of industrial structures, (3) through commercialization to guide market entities to utilise IP through finance, investment, government procurement, and industrial development. Also, the government would launch various pilot or demonstration projects for IP. Enterprises would be the principal entities in the creation and utilisation of IP through original innovation, joint innovation and secondary innovation based on imported technologies. (4) extensive education to promote the national moral concepts to be proud of innovation and honesty, with incorporation of IP knowledge set up in higher education institutes, which is the joint responsibility of CNIPA, the 
Ministry of Education, and the Ministry of Science \& Technology, is geared towards universities.

In terms of laws and regulations improvements, it is planned that the Patent Law needs to make advanced development plans according to the nation's strategies in the core industries of technology, regulates the process of turning a patent into a standard with the opinions from enterprises and industry organisations. For further detail, the State also pursues to further reduce examination time for high value patent applications to 16 months. It also stops granting awards for patent applications and gradually cancel awards for potent grants. The Trademark Law should be fully utilised to enrich the meaning of enterprise trademarks, adding values and improving the reputation by establishment of well-known trademarks. The State also aims to abolish local government funding and incentives for utility model, design and trademark applications. The rewards or subsidies for invention patents still apply. It should also be made use in the industrialisation of agriculture to improve the quality of the farm products. Further, the efficiency of examination needs to be improved with shorter time (with an average examination time to 4 months). The Copyright Law needs to intensify the punishments against piracy and focus on dealing with curbing the large-scale production, selling and dissemination of pirated goods.

Additionally, "trade secret“ infringements would all be severely punished in accordance with law. In regard to "national defense security“, the administration of IP needs to cover all links in national defence, an early warning mechanism shall be established, with an intermediary service system, and rules for keeping secrecy and declassification of IP needs to be further improved. In general, it is promised that the legislations would be more transparent, and more available channels for enterprises, industrial associations and the public to participate, such as setting up a high-quality database of basic IP information and an IP early-warning and 
emergency-response system. Revisions and legislative interpretations of IP laws also should be improved for handling new arising problems. More specifically over industries, the aspects of trade secrets, Gl, genetic resources, traditional knowledge (Chinese medicine in particular), and folklores will also be effectively protected and reasonably utilised.

VIII. Phase 1 Trade Agreement

Having listed a number of legal commitments made by China, it is now important to compare to what extent have Chinese laws changed corresponding to the demands by the US enshrined in Phase 1 Trade Agreement.

In this agreement China and the US have undertaken provisions with respects to intellectual property, technology transfer, and expansion of trade. China on its part, recognises the need to transform from a major IP consumer to a major IP producer. The Agreement states the transfer of technology should occur on voluntary, market-based terms that reflect mutual agreement. Enforcement of domestic laws of the other Party should be impartial, fair, and non-discriminatory. As a result, both Parties have agreed to establish a foundation and cooperation for addressing long-standing structural concerns, and that each Party of this Phase 1 trade deal should ensure that its obligations under this agreement are fully implemented, which China shall generate an action plan within 30 days to incorporate all measures . Therefore, in this section of analysis, it is interested in comparing to what extent has the current Chinese domestic law changed, in response to the commitments in this trade deal (refer to Annex 10).

In terms of Gl of trademark, it has been protected as certification or collective marks under the China Trademark Law regulated by CNIPA, Regulations on Protection of GI Products by CNIPA, and Administration of GI for Agricultural Products by Ministry of 
Agriculture and Rural Affairs. Specifically, it is defined in Article 16 of Trademark Law „the origin of the goods the special qualities, credibility or other characteristics of the goods and it is primarily determined by the natural factors or other humanistic factors of the place indicated“. Further, China has in response generally prohibited trademarks applied with malicious intent and consequently imposed a heavier financial sanction for trademark agent knowingly registers those with malicious intent . However, there is no further defining article on cancellation of International Agreements of $\mathrm{Gl}$ to be generic. On the contrary, the right holders have no right to prohibit others from properly using the generic name, graphics or such information indicates Gl. Additionally, China remains trademarks with Gl valid for whose registration is obtained in goodwill, or where geographical names have other meanings or constitute part of a collective trademark. As such, the domestic law does not mention misleading the public explicitly in the Chinese trade context, and grants a degree of freedom in its registration and Gl trademark interpretations. Further, in the aspects of e-commerce as specified in the draft amendments of Patent Law, the internet service provider who does not take necessary measure after receiving the notice, should be held jointly liable together with the internet user who infringes the patent right for the expanded damage. However, not only the liability is limited only up to expanded damage, the license of the internet service provider would not be revoked.

Generally speaking, there are changes made to China's judicial system to shift the burden of proof to the accused, which may help FIEs litigate more successfully against parties who violate their IPR. Also, if a dispute over the patent infringement involves a utility model patent or a design patent, it proposed to improve that relevant parties from both sides of the law suit may voluntarily provide the patent right evaluation report. It is a report through searching, analyzing, and assessing the relevant utility model or design to be served as evidence for trying or handling the patent infringement dispute. In the „Iron Fist“ action plan, it is also planned that 
expert witness and technical investigation would be established. China also subjects those engage in forms of trade secrets to criminal proceedings, it has increased statutory damages and provided punitive damages in general up to five times actual loss in trademark infringement and against unfair competition, with a maximum of RMB 5 million compensation . In terms of civil proceeding, the action plans have guaranteed to intensify punishments against manufacture and exports of pirated and counterfeit goods, the State also has implemented as required, such as destruction or disposal of raw materials at the request of right holders, and disciplinary punishments for administrative staff However, one could still argue on it low castigation level and also, to what extent have these judicial changes help FIEs address IPR more effectively in the courts remains to be seen .

Although China has promised to open up, it has never actually acknowledged the needs increase the importation of quality and affordable goods to domestic consumers, nor technology transfer as stated in Phase 1 Agreement. The Agreement has failed to address issues relating to the systemic structure such as state-owned enterprises and national security. Meanwhile, although China has promised equal treatment with provisions of Article 4 (Pre-entry national treatment), Article 15 (equal information disclosure of the setting of standards), Article 16 (equal treatment with government procurement), its outsized role of state-owned enterprises are still subsidised by the Chinese government. Also, in the aspect of confidentiality obligation, the Agreement requires that Chinese government agencies shall not disclose trade secrets without authorisation, and limits their access by strictly restricting to their official capacity. Although FIL and its Implementing Regulations thereof have stated equivalent rules, according to Article 6 of FIL, the State would protect the legitimate rights and interests of foreign investors, however, they shall not endanger China's national security or harm the public interest. Moreover, the controversial security system have even added broader and more complicated political considerations. China has not stated explicitly what may constitute as 
breaching national security nor how would such review mechanism operate in details. Further, both Parties also have addressed electronic intrusion as a form to infringe upon trade secret to some extent, which has implemented in China's domestic law in its judicial evidence and Competition law. In terms of its bilateral dispute-solution mechanism, apart from its exclusiveness to other countries, it is addressed that when an issue cannot be negotiated further, it may suspend obligations under Agreement or even adopt a remedial measure in good faith . Moreover, the Phase 1 Trade Agreement also requires China to increase its administrative enforcement, which China plans to expand its copyright administrative authorities to the county level. However, the effects would lead to further opaque bureaucracy with the creation of over 3,000 copyright offices in China-more than the rest of the world combined. As such, one would also need to question sustainability of the deal and the if the Phase one deal has really achieved meaningful changes.

Lastly, further specifications on various industries IP protections, which also apply to all concerning FIEs conduct investments in China could refer to Annex 11. Exclusive bilateral industrial policies between US and China would not be discussed in this research.

IX. Evaluation

(A) Further Clarifications

(1) The National Security Review (NSR) is becoming an increasingly important measure for the governmental administration in reviewing foreign investments all around the world. In China, the disclosure of information is deemed as a state secret if it could result in any one of the eight consequences, which are (i)endangering the ability of the state to consolidate and defend its power, (ii) affecting national unity, ethnic unity or social stability (iii) harming the political or economic interests of the state in its dealings with foreign countries, (iv) affecting the 
security of state leaders or top foreign officials, (v) hindering important security or defense work of the state, (vi)causing a decrease in the reliability, or a loss of effectiveness to, the measures used to safeguard state secrets, (vii) weakening the economic and technological strength of the state, (viii) causing State organs to lose the ability to exercise their authority according to the law. As such, the wide scope of considerations deemed as a state secret could be particular sensitive when FIEs invest in key technologies that would affect national defense security, national economic stability, social order, or research and development capacity for key technologies related to national security . Also, a more extensive NSR regime applies to the pilot free trade zones. In May 2015, FTZ NSR Notice came into effect which extends the scope of NSR to foreign investment in certain additional sectors, (1) cultural security and public morality and (2) State cybersecurity.

Currently, the review system is effective in China but it still relies on the provisions in the Notice 2011 and the Provisions 2011 for now. Pursuant to the Notice 2011, key technologies are divided into two sub-categories. The first category involves with foreign takeovers „(1) in the military industry and industries supportive to the military industry, (2) of entities adjacent to major or sensitive military facilities, and (3) of other defence-related entities, regardless of whether the foreign investor seeks control of the target company." . The second category refers to the situation where foreign investors aim to obtain „actual control“ of the important domestic industries, such as agriculture, energy, infrastructure, etc . The definition of „actual control“ is in general that foreign investor holds the exceeding of $50 \%$ shareholding threshold, nonetheless, it does not exempt for those under this percentage as long as there is evidence to indicate a de facto controlling power exists by other means However, the question is, has the Chinese NSR fulfilled the requirements of reasonableness and proportionality? 
The Chinese NRS has a significant margin of discretion/interference in practice to determine to what extent a foreign investment may negatively influence national economy or basic social order since there are no further definitions on what may influence on the stable functioning of national economy. The vague phrases would potentially have the risks of being utilised as catch-all phases in the review practice with no credible references by the administrative members . However, compared to the past „case-by-case“ approval system, the new Chinese laws provide workable administrative procedures and tangible criteria on national security which at least have set out the „rules of the game“. Overall, China would need to continually increase its transparency and predictability, and reduce the over-inclusiveness of the concept of national security, as it would potentially lead to excessive administrative discretion in the review process, and thus results to disproportionate regulation and have an deterrent effect to the future incoming FDI .

(2) The international investment principle of "legal security“ is to provide full protection and security for the investors by the State, and to intervene where it had the power and duty to do so to protect the normal ability of the investor's business to function, and not harassed by the political and economic domestic powers that be . Often, administrative malfeasance, misfeasance and nonfeasance may affect the FDI adversely. In the amended Chinese laws, administrative organs have been required to improve in the aspects of non-coercion for technology transfer, keeping confidential of trade secrets, and use of their power. Violations of the provisions could result themselves in penalty, and in severe cases, they shall be proceeded with criminal punishments. „Abuse of powers“ often finds expressions in making self-righteous, unreasonable and arbitrary decisions, while ,ignoring duties“ refers to the state organ functionaries being extremely irresponsible, performing duties improperly and cause heavy losses to public property, or interests of the state and people. Questionably, for example, it is stated in the Competition Law „minor illegal acts without any harmful consequences" conducted by the authorities shall only be 
subjected to "mitigated or no administrative punishment“. To clarify the underlying criteria, according to The Civil Servant Law Article 30 , judicial administrative staff shall be given punishments of warning, demerit, gross demerit, demotion, dismissal from post and expulsion, if they misuse powers, ignore duties, or even abuse their power for personal gains. According to the Criminal Law Article 397 , the „harmful consequences" could be heavy losses to public property of the interest of the state and the people, and they shall receive either with a maximum of 3 years for serious harmfulness, or 3-7 years for especially serious cases for abuse or ignoring his duty. Further, „malpractices“ are those for personal gains or misusing powers shall receive a maximum of 5 years, or 5-10 years for especially serious cases.

(3) To handle IP law enforcement, the action plans only mention briefly that litigation system needs to be improved including judicial authentication, expert witnesses and technical investigation, the system of provisional measures prior to action involving IP, and a mechanism for reviewing IP for important economic events. To elaborate the concepts further, the judicial authentication system in China has actually not reached a consensus on the concept of judicial authentication. According to the decision passed by the Standing Committee in 2005, it is defined as ,activities conducted by expert witnesses to identify, judge special issues involved in litigation and provide expert opinions thereof through scientific and technological means". It involves with the whole procedure being legal, with no conflict of interest between authenticators and clients, and to verify the goods with scientific evidence As such, judicial authentication possesses the properties of statutory nature (lawfulness), neutrality (independence) and objectiveness (authenticity). When it applies to IP, this type of evidence could be useful such as in authenticating IP forgeries or signatures. By introducing diversified technical fact-finding mechanism with the help of technical assistance, the specialised IP Courts could improve effectiveness of technical investigation and therefore ensure the neutrality and scientific reliability in the process . 
In terms of administration, the action plans state that law-enforcement departments needs to speed up the referral of criminal cases involving IP to judicial organs, and judicial organs should make greater efforts to receive criminal cases involving IP. Further, more human resources and professional trainings are needed to administer IP. In practice, 18 specialized regional IP tribunals has been established in the capital or important cities of fifteen provinces are subordinate to the local Intermediate People's Courts. Also, the Pilot Program of the SPC on the establishment of an IP-specialized tribunal began operation on 1 January 2019 to hear appeals in civil and administrative cases of technology-related IP disputes nationwide, which can be seen as a process to centralise the exclusive jurisdiction over technology-related IP that are highly technical and complex. The IP Courts have worked hard to enhance productivity and efficiency by simplifying certain documents or diversifying mechanisms for dispute resolution, such as by broadening the scope of pre-trial mediation As result, for example, the average adjudication time of foreign-related IP cases by Beijing IP Court is only 4 months, while that in major European countries is about 18 months . China thus, has been continuously improving its trial system for IP and optimising the efficiency of judicial organs as part of its effort to build on IP judicial infrastructure.

(4) In order to foster domestic communications with foreign investors, the Chinese government is developing service awareness with two service systems. Firstly, a new foreign investment service system would serve for consultation purposes of the laws . According to the needs of certain regional economic and social development in China, the State would also guide foreign investors to invest in specific industries and fields and allow them enjoying some preferential treatment. The State Council would also establish a complaint mechanism for FIEs to coordinate problems of administrative organs, and additionally file administrative lawsuit if infringed upon their legitimate rights and interests. The basic features of such complaint 
mechanism has been amended in "the Draft Measures“. In March 2020. The complaint mechanism relies principally on communication, concession and understanding between a complainant and the respondent . It, however, does not prevent a complainant from seeking other remedies, such as administrative litigation if consensus cannot be achieved. The advantages of such complaint mechanism are it could enable the parties to resolve their disputes and thus saving time and costs of litigations. The new draft measure has been improved in terms of prolongation of the maximum time allowed for processing complaints due to complexities of administration-related issues, explicit confidentiality protection for commercial credentials, and a withdrawal mechanism for the interests of complainant. Also, the result of settle agreement reached would be binding, the respondent would be held accountable if he fails to comply. However, there has still not been a guideline for assessing a respondent's compliance with its obligations, and in practice, the scope of such DSM might be minor since a consensus is usually reached through mutual concessions. Also, the complainant still needs to be prepared to seek alternative remedies if such dispute could not be resolved.

\section{(B) Unclarity}

FIL explicitly specifies that foreign investment includes indirect as well as direct foreign investment, indicating, ,investments made by foreign investors in the construction of specific projects within the PRC without establishing FIEs or acquiring the shares, equity interests, property shares or other similar rights and interests in a Chinese domestic enterprise." However, it does not explain what types of „specific project“ and what constitutes as an „indirect foreign investment“ which would be an important characterisation in respect to whether or not to implement the negative lists. Since the FIEs could adopt forms of „penetration principle," which is "a certain component of foreign ownership would trigger foreign investment regulations...even if such foreign ownership is indirect and diluted". One form of „penetration principle“ commonly used in China by foreign investors is the Variable 
Interest Entity (VIE) structure refers to "an entity established in China which is fully or partially foreign owned ("Controlling Company") has control over an operating company ("Operation Company") which holds the necessary license(s) to operate in a FDI restricted or prohibited sector." . VIE could be regulated strictly with the established national security review system. However, the current procedure is unclear about neither the legitimate operation of VIE structure or how it would be required to go through the security review system. It is therefore expected to further clarify which level of penetration may be deemed material, limitations of indirect foreign investment, and the applicable administrative methods .

Also, FIL does not contain any concept of "equity joint venture contracts“ or "contractual joint venture contracts," the concepts of "Sino-foreign equity joint venture contracts" and "Sino-foreign contractual joint venture contracts" used in Article 126 of the Contract Law (1999) were derived from the previous Three FDI Laws. Nonetheless, upon the implementation of FIL taking effect, those previous laws mentioned are expected to be repealed. As results, the existing terms will lose their legal basis, it is also expected that the Contract Law would be amended consequently as it is not clear if the investors will be given flexibility to choose the governing law of their investment agreement.

The Article 2 of FIL in regard to the scope of investment, „investment in new projects" would also need further clarification as what constitutes as a new project and how to apply the foreign investment administration system, such as information reporting system, security review system, etc . Moreover, FIL grants a five-year transition period after the effective date, during which the FIEs could keep their original organisation forms. However, the consequences if the transitional period expires while the parties still have not reached the agreement, or have not gone through the relevant approval or filing procedures are not clear. 
(C) Incoherence

Typically, the implementation regulations supposed to provide more details and progresses than the law, but its Implementation Regulation of FIL is repeating FIL again without much interpreting. Also, there could be some discrepancies over the areas of remedy for expropriation and change of policy commitments. Firstly, Article 21 of Implementation Regulation mentions any expropriation targeting any investment made by foreign investors shall be compensated based on the „market value" of the expropriated investment. However, under FIL, the standard used for determination is "fair and reasonable". Admittedly, it is more accessible to evaluate based on the market value than a generic standard, but it should be taken notice that these two terms cannot be used interchangeably . Secondly, in Article 29 of FIL states that local governments need to fulfil the policy commitments strictly. However in Article 28 of Implementation Regulations states otherwise that they shall fulfil the commitments, or if it is necessary to change commitments due to national interests procedures, and if as such, fair and reasonable compensation shall be paid to foreign investors or FIEs who have suffered any losses as a result of such changes. It is seen that rather than strict legality, implementing regulations could be still subjected to political flexibility. Also again, the mechanism of compensation changes to "fair and reasonable" principle, not the aforementioned market value in Article 21.

There is also not enough information yet for the new implementations of the systems of negative lists and the national security review. The concerns are if the new systems correspond to the existing regulations or there would be new regulations, and how would the State solve the potential incoherence between the new and the old regulations.

(D) Under-emphasis 


\section{JOSHA}

Journal of Science, Humanities and Arts

The Article 4 of Trademark Law states that malicious trademarks that are not intended for use shall be rejected in the application for registration. Arguably, it is the intent to use which could cause actual harm to the goodwill and economic interests of the legitimate brand owner, as the savvy trademark pirates could easily diversify themselves and use different offshore companies to get rid of scrutiny by CNIPA and brand owners. Nonetheless, the good point is CNIPA also states that further measure is to include bad faith filing as a type of serious dishonest behaviour affecting social credit and also receiving „joint punishment.“ It would include enhanced supervision and restrictions on import and export, dishonesty recorded in financial credit information database, and curbing on government fundings. These punishments could therefore act as deterrent against pirated trademarks. The other problem of Trademark registration is its huge quantities of applications as trademark is often seen as a commodity, cheap to obtain and carry the potential of a significant profit when sold at later date. Therefore, the law should provide legal ground to interpret trademark principle of „genuine use“.

Besides, E-commerce has untouched on the areas of data protection, unauthorised online intrusions that been emphasised in Phase 1 Trade Agreement. Also, the castigation levels for punitive damages which although have raised up to five times in the infringements IPRs, they are still very low. The economic benefits of the piracy and infringers could easily outweigh its compensative loss to promote meaningful legal liabilities.

Moreover, the SPC's Judicial Interpretation Agenda for 2020 („2020 Judicial Interpretation Agenda“) was adopted by the SPC Trial Committee in March 2020. It is divided into two categories, Case I Projects, which are required to be completed by the end of 2020; 11 in the Class II Projects, which are required to be completed in the first half of 2021. It covers fields such as the enforcement, security, pre-litigation property preservation, civil code, criminal cases, administrative cases, etc. However, 
there is still an under-emphasis on the courts mentioned in the laws, which have only provided one sweeping clause over the need of improvements in judicial authentication, expert witnesses and provisional measures .

(E) In summary

Some outstanding issues over the Chinese domestic laws on IPRs are that they have selective focus on IPRs, under-emphasis on the courts, definitions and strategic goals lack of clarity and often consist of "catch-all sweeping clauses," and lack of historical context or data to ensure that the action plans actually deliver results. Nonetheless, one must also take in considerations of the Chinese tradition and its socio-political environment, as its "rule of law" does not always cohere with the Western concept.

Firstly, in the Chinese practice, the administrative discretion has always had wider latitude. Noticeably, there are many examples of unclear phrases in the provisions can be seen as problematic in international standard, such as all the Articles are all formulated with the reference to,,the State shall act" without precisely stating which organ. Another example is when administrative organs face „special circumstances“, they are not required to consistently practice certain provisions when as deemed necessary for the public interest. From another perspective, it can also be said the Chinese vagueness of terms reflects the inherent flexibility of the Chinese concept . As result, although there have been proposed IP service-oriented mechanisms, the issue of abstract appropriateness of these mechanisms should be considered separately from their actual efficiency. Additionally, in a socialist context, the applicable doctrine is that legal rules represent the will of the people, any unexpressed or unclear laws should not be construed in a way against the interest of the People, the legislator, the party, which are all part of the same single political power . 
Besides, it is also well-known that the Chinese underlying political doctrine is that there is no separation of powers. The key concept in the Chinese organization is the role of supervision from central to local government. However, its complex interactions amongst sources at the different hierarchical and territorial levels, could also cause contradictions between laws and regulations. Specifically, rules from the central government passed by its standing committee shall be consistently applied at local levels with a degree of flexibility; the city-level government shall also have its own level of flexibility but still consistently applying the regulations of the provincial government. As such, there would be instances of inconsistencies in the application of law. Since the overarching power is the NPC, it is also vested with the power of interpreting the rules and its interpretation would have the same force of the interpreted law. On other occasions, Party rules have been developed and applied within the Party environment have subsequently become legislative rules. Therefore, the functions of the court are very limited. It could only promote the administrative enforcement of the laws by means of enhanced supervision, improvement of the government's works at all levels and its discharge in accordance to the laws. The highest level of the Chinese court, SPC, could only perform several key functions such as controlling the activities of lower courts through its decisions, directives and supervision, harmonising the application of law within the framework of the system of legal rules, as well as within the policies of the Party .

Therefore, the Chinese „rule of law“ can be very different from that of Western-style. Law and enforcement could in fact be two different issues. Enforcement is neither a neutral, technical issue, nor an automatic consequence of law, which can be easily under-enforced or over-enforced according to policy needs. In the evaluation of IPRs protections of foreign investments, it is only certain to conclude the Chinese laws have been progressively applying the international investment law standards. 


\section{Conclusion}

This thesis has focused on comparisons between different bodies of law related to IPRs in China. It has discussed the extent of the Chinese laws cohere with the international minimum standard, the aspects of changes contrasting its past provisions, the specific domestic measures of laws corresponded by the State, and finally the extent of implementations of the Phase 1 Trade Agreement. This legal analysis has shown the current Chinese laws have been adjusted by closely committing to the Phase 1 Trade Agreement, in the aspects of its opening-up policies, equal treatment, application of legal liabilities, procedural measures, and protections on trade secrets. Although it could still be contended the aspects of Geographical Indication of trademark and E-commerce infringements have not been implemented fully yet, also the amended laws have generated a controversial National Security Review System which was not negotiated in the Phase 1 Trade Agreement.

Taken into consideration of the Chinese concept of „rule of law“ and its extra flexibility required to accommodate a market economy within a socialist environment, foreign investors shall not be too optimistic on the certainty of enforcement of current laws. Although it is fair to conclude the level of intellectual property protections has increased, foreign investors shall bear in mind that there are degrees of political or administrative discretion in the general application of legal rules, according to the different relevant areas. Laws and regulations are intertwined with the social economy. As China's economy is expanding through trading and investments, an increased role of law in Chinese life is clearly detectable, and thus 
contraction of the laws with Chinese characteristics would also be expected to constantly adjust to the international standards in the future.

China always seems to prefer a different approach, interesting comparisons and research could be done to find similarities and differences between the Chinese transitions over its history of law theories and the Western evolution of laws. These studies would allow for a better understanding of the relation amongst law, and critically evaluate the current international law system if different approaches (non-western styles) could also be adopted.

XI. Annex 4-13 
XII. Bibliography

\section{Legislations}

Agreement on Trade-Related Aspects of Intellectual Property Rights (effective on 1 Jan 1995)

Amendment to the Patent Law of the People's Republic of China (Draft)

Anti-Unfair Competition Law of the People's Republic of China (2019 Amendment) (effective on 23 April 2019)

Contract Law of The People's Republic of China (adopted 15 Mar 2019)

Decision of the State Council to Amend Certain Administrative Regulations (effective on 02 Mar 2019, partially invalid)

Decision of the State Council to Amend Certain Administrative Regulations (effective on 02 Mar 2019) 
Deeply implement the national intellectual property strategy in 2020 to accelerate the construction of an intellectual property power promotion plan (effective on 13 May 2020)

Economic And Trade Agreement Between The Governance of the United States of America and The Government of the People's Republic of China (signed 15 Jan 2020 , entered into force 60 days after)

Encourage Foreign Investment Industry Catalog (2019 edition)

Foreign Investment Law of the People's Republic of China (effective on 15 Mar 2019) Implementing Regulations of The Foreign Investment Law of The People's Republic of China (effective on 1 Jan 2020)

Outline of the National Intellectual Property Strategy (issued on 28 April 2020)

Regulations on the Implementation of the Law of People's Republic of China on Guarding State Secrets (effective 1 Mar 2014)

Regulations for the Implementation of the Foreign Investment Law of the Republic of China (effective on 31 Dec 2019)

Regulations on Technology Import and Export Administration of the People's Republic of China (effective on 18 March 2019)

Rules for the Implementation of the Law of the People's Republic of China on Foreign-capital Enterprises (adopted 16 April 2000)

Special Management Measures For Foreign Investment Access (Negative list) (2019 edition)

The Trans-Pacific Partnership Agreement Implementation Act (signed on 4 Feb 2016) Trademark Law of the People's Republic of China (2019 Amendment) (effective on 1 Nov 2019)

The Agreement on Trade-Related Aspects of Intellectual Property Rights (TRIPS) General Agreement on Tariffs and Trade (1994)

The Constitution law of People's Republic of China (1982, amended 11 March 2018) 
Understanding on Rules and Procedures Governing The Settlement of Disputes

Case

US - Continued Suspension / Canada - Continued Suspension (21 Nov 2008) WT/DS321/AB/R

Journals and Reports

Arie Reich, 'The Effectiveness of the WTO Dispute Settlement System: A Statistical Analysis' [2017] 11 EUI

Bertram Boie, ,The Protection of Intellectual Property Rights through Bilateral Investment Treaties: Is there a TRIPS-plus Dimension?‘ [2010] 19 NCCR

Björn Ahl, ,Summary: The Application of International Treaties in China' [2009] 207 MPG 355

Christoph Schreuer, 'Full Protection and Security', [2010] JIDS 1

Jingchao Dai, ,Intellectual Property Rights Protection, Foreign Technology Introduction and FDI-Based on the Provincial-Level Panel Data of China [2019] 8 SPI 30

EUTAXESS, IIPR in China: Guidance for

Researchers'<https://ec.europa.eu/research/iscp/pdf/sfic/ipr-in-china-guidelines_en. pdf $>$ accessed on 15 May 2020

Ge Chen and Max J. Zenglein, ,The global faces of China's incomplete reforms: a perspective from China's new intellectual property regime'[2019] 17 CEBS 425 Hogan Lovells, ,The Foreign Investment Law Implementation Regulations come into force: but why all the last minute changes? <https://www.hoganlovells.com/ /media/hogan-lovells/pdf/2020-pdfs/2020_01_23_ foreign_investment_law_implementation_regulation.pdf?la=en> accessed 4 May 2020 
Huiwen Lai, Keith E. Maskus, and Lei Yang, ,Intellectual property enforcement, exports and productivity of heterogeneous firms in developing countries: Evidence from China، [2018] EER 123

Ignazio Castellucci, 'Rule of Law with Chinese Characteristics' [2007] 13 ASICL 35

Jon R, Johnson, 'The Art of Breaking the Deal: What President Trump Can and Can't Do About NAFTA' [2017] C.D.HOWE

Jürgen Bering and others, 'General Public International Law and International Investment Law: A Research Sketch on Selected Issues' [2011] TELC

Jyh-An Lee and Yuangzi Li, ,The Obscure Consumer in the Chinese Intellectual Property Law‘ [2019] 24 CUHG

Jyh-An Lee, ,Shifting IP Battleground in the U.S.-China Trade War' [2020] 4 CUHG

Kennan Castel-Fodor, 'Providing a Release Valve: The U.S.-China Experience with the WTO Dispute Settlement System' [2013] 64 CWRL 201

Kenneth J. Vandevelde, 'A Unified Theory of Fair and Equitable Treatment' [2011] 43 NYUJ Int'l L 43

Lee Branstetter and others, ,Intellectual Property Rights, Imitation, and Foreign Direct Investment: Theory and Evidence‘ [2007] 13033 NBER WP

OECD, 'Fair and Equitable Treatment Standard in International Investment Law', OECD Working Papers on International Investment' [2004] 3 OECD

Peter Lunenborg, ,US-China trade deal: preliminary analysis of the text from WTO perspective‘ [2020] 72 SC

Qing Liu, Ruosi Lu and Chao Yang. ,International joint ventures and technology diffusion: Evidence from China‘ [2019] 43 TWE 146

Ryan Cardwell and Pascal Ghazalian, ,The Effects of the TRIPS Agreement on International Protection of Intellectual Property Rights‘ [2012] 26 ITJ 19

Silke von Lewinski, ,Intellectual Property, Nationality, and Non-Discrimination“ [2001] MPI 
Nikolas Papageorgiadis and others, ,The characteristics of intellectual property rights regimes: How formal and informal institutions affect outward FDI location‘ [2020] 29 IBR

Toulope Anthony Adekola, ,US-China trade war and the WTO dispute settlement mechanism‘ [2019] ITL

USTR, 2019 Report to Congress On China's WTO Compliance (March 2020) accessed on 10 May 2020

USTR, Special 301 Report (April 2019) accessed on 1 March 2020

Wei Zhang, ,Understanding The Law of Torts in China: A Political Economy Perspective‘ [2018] 11 UPALR 171

Zou Keyuan, 'International Law in the Chinese Domestic Context' [2010] 44 VULR 935

\section{Book References}

Cheng Bian, National Security Review of Foreign Investment: A Comparative Legal Analysis of China, the United States and the European Union (Routledge 2020)

Esther Lam, China and the WTO: A Long March towards the Rule of Law (Kluwer Law International B.V. 2009)

Jola Gjuzi, Stabilization Clauses in International Investment Law: A Sustainable Development Approach (Springer, 2018)

John Linarelli, Margot Salomon and M Sornarajah, The Misery of International Law: Confrontations with Injustice in the Global Economy (OUP 2018)

Lam E, China and the WTO: A Long March towards the Rule of Law (Kluwer Law International B.V. 2009).

Lixin Xu (tr), Questions and Answers on the Regulations of the People's Republic of China on Technology Import and Export Administration (CITIC 2002)

Peter Chroziel and Moritz Lorenz, Intellectual Property and Competition Law (Kulwer Law International B.V. 2016) 
Xiaojun Li, ,Bureaucratic Politics and Lawmaking under Xi Jinping:The Case of China's New Foreign Investment Law' (UBC, 01 Jan 2020)<https://www.academia.edu/41477819/Bureaucratic_Politics_and_Lawmaking _under_Xi_Jinping_The_Case_of_Chinas_New_Foreign_Investment_Law $>$ Accessed on 19 February, 2020.

Susan Trevaskes, Policing Serious Crime in China: From ,strike Hard' to ,kill Fewer" (Routledge 2010)

Yong'an Ren and Xianyang Lu, A New Study on the Judicial Administrative System with Chinese Characteristics (Springer 2020)

Zhipeng He and Lu Sun, A Chinese Theory of International Law (Springer 2020)

Websites and Blogs

Adam Barone, 'Free Trade Agreement (FTA)' (Investopedia, 29 Jan 2020)<https://www.investopedia.com/terms/f/free-trade.asp> accessed 30 May 2020.

Alizee Zheng, 'China releases updated versions of its two negative lists and encouraged foreign investment catalogue to promote foreign investment' (Herbert $\begin{array}{lllll}\text { Smith } & \text { Freehills, } & 13 & \text { Aug }\end{array}$ $<$ https://sites-herbertsmithfreehills.vuturevx.com/95/20498/compose-email/china-rel eases-updated-versions-of-its-two-negative-lists-and-encouraged-foreign-investme nt-catalogue-to-promote-foreign-investment.asp>accessed on 13 May 2020

Björn Ahl, ,Summary: The Application of International Treaties in China' [2009] 207 MPG 355

Caroline Banton, 'Royalty' (Investopedia, $13 \quad$ Sep 2019)<https://www.investopedia.com/terms/r/royalty.asp> accessed on 13 June 2020. 
CECC, 'China's State Organizational Structure' (CECC)<https://www.cecc.gov/chinas-state-organizational-structure>accessed on 14 June 2020.

CECC, 'Silencing Critics by Exploiting National Security and State Secrets Laws' (CECC) $<$ https://www.cecc.gov/silencing-critics-by-exploiting-national-security-and-state-s ecrets-laws > accessed on 10 June 2020.

CNIPA (tr), 'Notice of the Office of the Inter-Ministerial Joint Meeting on the Implementation of the Intellectual Property Strategy of the State Council on Issuing the "Plan for Further Implementation of the National Intellectual Property Strategy to Accelerate the Construction of a Powerful Intellectual Property Country in 2020", (CNIPA, 15 May 2020) <http://www.cnipa.gov.cn/gztz/1148642.htm> accessed on 5 June 2020.

Hannibal El-Mohtar, ,China's New Foreign Investment Law and Intellectual Property $\begin{array}{lllll}\text { Protections، (China } & \text { Law } & \text { Blog, } & 31 & \text { Dec }\end{array}$ 2019)<https://www.chinalawblog.com/2019/12/chinas-new-foreign-investment-lawand-intellectual-property-protections-part-2.html> Accessed on 18 Feb 2020.

Hebert Smith Freehills, 'National security review regime under the new foreign investment law' (Lexology, $06 \quad$ Feb $<$ https://www.lexology.com/library/detail.aspx?g=61793b05-6109-4a68-9d02-5cf3f7 dae384> accessed on 20 May 2020.

INTA, ' INTA Comments on the Draft Certain Provisions for Regulating Application for Trademark Registration'(INTA, $14 \quad$ Mar 2019 ) <https://www.inta.org/Advocacy/Documents/2019/INTA\%20Comments\%20on\%20 
CNIPA\%20Regulation\%20addressing\%20bad-faith\%20application\%20-\%20EN.pdf $>$ accessed on 7 June 2020.

IP Australia,'Patents and designs in China' (IP Australia, 24 April 2020) $<$ https://www.ipaustralia.gov.au/understanding-ip/taking-your-ip-global/ip-protectio n-china/patents-and-designs-china> accessed on 10 June 2020.

IP News, 'Amendments to China's Trademark Law will be implemented on $\begin{array}{lllll}\text { November } & 1, & 2019 & & \end{array}$ 2019)<https://www.ccpit-patent.com.cn/node/6201 >accessed on 10 June 2020.

He Jing and Wu Li, ,China patent: China publishes revised Draft Amendments to the $\begin{array}{lllll}\text { Patent Law } & \text { (Managing } & \text { IP, } & 04 & \text { Feb }\end{array}$ 2019)<https://www.managingip.com/article/b1 kblyjkjdvwtq/china-patent-china-publi shes-revised-draft-amendments-to-the-patent-law> accessed on 7 June 2020

Jon R, Johnson, 'The Art of Breaking the Deal: What President Trump Can and Can't Do About NAFTA' [2017] C.D.HOWE

Jürgen Bering and others, 'General Public International Law and International Investment Law: A Research Sketch on Selected Issues' [2011] TELC

Kaiding Wang and others, 'Into A New Era: Changes and Challenges in the Foreign Investment Legal Regime of China' (kwm, 15 Mar 2019) $<$ https://www.kwm.com/en/cn/knowledge/insights/new-foreign-investment-law-201 90315> accessed on 13 May 2020

Kenneth J. Vandevelde, 'A Unified Theory of Fair and Equitable Treatment' [2011] 43 NYUJ Int'I L 43

Leaf-legal, 'Corporate Social Credit system in China: how to check your status?' (Leaf-legal, 
$<$ https://www.leaf-legal.com/corporate-social-credit-system-in-china-how-to-checkwhere-do-you-stand/> accessed on 1 June 2020

Loke-Khoon Tan, 'China's Amended Trademark Law to Curb bad Faith Filings' (Baker McKenzie, 04 Nov 2019)<https://www.bakermckenzie.com/en/insight/publications/2019/11/chinas-am ended-trademark-law> accessed 05 May 2020.

Mark Cohen 'Antitrust and Licensing on June 3, plus Standards, Data and E-Commerce: Plenty for Everybody' (China IPR, 20 May 2020) <https://chinaipr.com/2020/05/29/antitrust-licensing-standards-data-and-e-commer ce-plenty-for-everybody/>accessed on 3 June 2020

Mark Cohen 'Is It In There - CNIPA's "Phase 1" IP Action Plan' (China IPR, 22 April 2020)

$<$ https://chinaipr.com/2020/04/22/is-it-in-there-cnipas-phase-1-ip-action-plan/>acc essed on 3 June 2020

Mark Cohen 'SPC's 2020 IP-Related Judicial Interpretation Agenda' (China IPR, 31 Mar

2020)<https://chinaipr.com/2020/03/31/spcs-2020-ip-related-judicial-interpretationagenda/>accessed on 3 June 2020

Mark Cohen, 'THE TIER IS REVISED...' (China IPR, 18 March 2019)<https://chinaipr.com/2019/03/18/the-tier-is-revised/>accessed on 08 June 2020

OECD, 'Fair and Equitable Treatment Standard in International Investment Law', OECD Working Papers on International Investment' [2004] 3 OECD

Richard Altieri and Benjamin Della Rocca, 'U.S. and China Sign "Phase One" Trade Deal but Leave Key Issues Unresolved' (Lawfare, 22 Jan 2020) 
$<$ https://www.lawfareblog.com/us-and-china-sign-phase-one-trade-deal-leave-key-i ssues-unresolved> accessed on 20 May 2020.

Ryan Cardwell and Pascal Ghazalian, ,The Effects of the TRIPS Agreement on International Protection of Intellectual Property Rights، [2012] 26 ITJ 19

SAMR (tr), 'Notice of the General Administration of Market Supervision on Printing and Distributing the "Intellectual Property Enforcement "Iron Fist" Action Plan for 2020“ ' (SAMR, $28 \quad$ April 2020) <http://gkml.samr.gov.cn/nsjg/zfjcj/202004/t20200428_314779.html> accessed on 14 June 2020.

Squire Patton Boggs, 'China Foreign Investment Law: MOFCOM Issues Draft Complaint Mechanism' (Squire Patton Boggs, April 2020)<https://www.squirepattonboggs.com/-/media/files/insights/publications/2020 /04/china-foreign-investment-law-mofcom-issues-draft-complaint-mechanism/china -foreign-investment-law-mofcom-issues-draft-complaint-mechanism.pdf> accessed on 14 June 2020.

Stephen Yang, 'China: Highlights Of The Draft 4th Amendment To The Patent Law Published On January 4, 2019' (Mondaq, 13 Feb 2019) <https://www.mondaq.com/china/patent/781174/highlights-of-the-draft-4th-amend ment-to-the-patent-law-published-on-january-4-2019> accessed 03 May 2020.

Steven Grimes, 'China Revises Anti-Unfair Competition Law to Further Enhance Trade Secret Protection' (Winston\&Strawn LLP, 13 May 2019) $<$ https://www.winston.com/en/privacy-law-corner/china-revises-anti-unfair-competit ion-law-to-further-enhance-trade-secret-protection.html> accessed 03 May 2020

Ton Zuildwijk, 'Understanding the Intellectual Property Disputes between China and the United States' (CIGI, 15 May 2020) 
$<$ https://www.cigionline.org/articles/understanding-intellectual-property-disputes-be tween-china-and-united-states> accessed on 20 May 2020

Wanhuida Peksung IP Group, 'Fourth revision of China's Trademark Law' (World Trademark Review, 20 May 2019)<https://www.worldtrademarkreview.com/fourth-revision-chinas-trademark-la w> accessed on 13 June 2020.

Wei Zhang, ,Understanding The Law of Torts in China: A Political Economy Perspective، [2018] 11 UPALR 171

WIPO, 'Summary of the Paris Convention for the Protection of Industrial Property (1883)' (WIPO, 2014)<https://www.wipo.int/treaties/en/ip/paris/summary_paris.html> accessed on 10 June 2020.

WTO, 'DS362: China - Measures Affecting the Protection and Enforcement of Intellectual Property Rights“ (WTO)

WTO, 'DS543: China - Certain Measures Concerning the Protection of Intellectual Property Rights' (WTO)

WTO, 'TRIPS : A More Detailed Overview of the TRIPS Agreement' (WTO) $<$ https://www.wto.org/english/tratop_e/trips_e/intel2_e.htm>accessed on 13 June 2020.

WTO,'WTO Bodies involved in the dispute settlement process' (WTO)<https://www.wto.org/english/tratop_e/dispu_e/disp_settlement_cbt_e/c3s1p 1_e.htm> accessed on 10 June 2020.

Xiaomei Fu, 'At a glance: the implementation of China's Foreign Investment Law' (Rödl \& Partner, $\quad 23$ Jan 2020)<https://www.roedl.com/insights/china-implementation-foreign-investment-law $>$ accessed on 10 June 2020. 
Xu Ping, 'Securing Electronic Data Evidence in IP Cases under the New Evidence

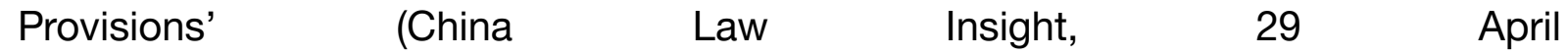
2020)<https://www.chinalawinsight.com/2020/04/articles/intellectual-property/securi ng-electronic-data-evidence-in-ip-cases-under-the-new-evidence-provisions/> accessed on 30 May 2020

Xu Ping, 'Variable Interest Entity (VIE) Structure for Foreign Investment in the PRC May Face Challenge'(China Law Insight, 20 Oct 2011)<https://www.chinalawinsight.com/2011/10/articles/foreign-investment/variabl e-interest-entity-vie-structure-for-foreign-investment-in-the-prc-may-face-challenge/ $>$ accessed on 15 May 2020

Yalkin Tolga, 'The International Minimum Standard and Investment Law: The Proof is in the Pudding' (EJIL Talk, 03 Aug 2009)<https://www.ejiltalk.org/international-minimum-standard/> accessed on 8 June 2020

Zoey Zhang, 'China's 2019 Trademark Law Amendment: What's New'(China Briefing, 22 Jan 2020)<https://www.china-briefing.com/news/china-2019-trademark-law-amendmen t-whats-new/> accessed 03 May 2020

Zoey Zhang, 'How to Use China's Negative Lists and Foreign Investment

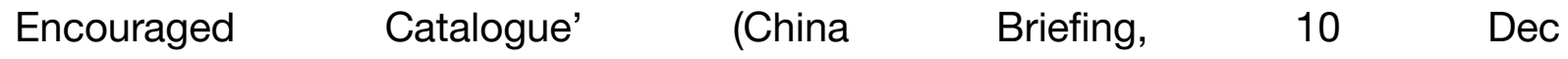
2019)<https://www.china-briefing.com/news/china-fdi-policy-negative-lists-encoura ged-catalogues/> accessed 05 May 2020

Zou Keyuan, 'International Law in the Chinese Domestic Context' [2010] 44 VULR 935

Law Library. „Law Library-American Law and Legal Information“ (Lawjrank) <https://law.jrank.org/> accessed on 13 May 2020 
Figure captions and tables:

Diagram 1: Interrelationships between four bodies of IPR protections

Diagram 2: Related legal documents in this research

Digram 3: A Timeline of US-China Trade war

Annex 4: The following list, however, is not exhaustive, it outlines major imposed or lifted restrictions on several industries.

Annex 5: The scope of restrictions for trademark registration

Annex 6: Application of import licensing of restricted technology and freely imported technology

Annex 7: Application of export licensing of restricted technology and freely exported technology

Annex 8: Application procedures to registration of trademark

Annex 9: Unfair Competitions legal liabilities

Annex 10: Trademark infringement legal liabilities

Annex 11: Comparisons between the Phase 1 trade deal and the current Chinese domestic law

Annex 12: Further specifications on various industries IP protections mentioned in Phase 1 trade deal, concerning to all countries.

Annex 13: Aspects of IP reforms comparing the current Chinese domestic law and the past 


\section{JOSHA}

Journal of Science, Humanities and Arts

February 2021

Volume 8 , Issue 1

\section{About the Author:}

Mei Lin Lyu, obtained her BA Liberal Arts and Sciences, with specialization in Governance at University of Freiburg, Germany. She is now pursuing MA Greek and Eastern Mediterranean Archaeology in National University of Athens, Greece. She is also an entrepreneur and manages "ILIAMEI Natural Health Products and Cosmetics", specializing in olive oil.

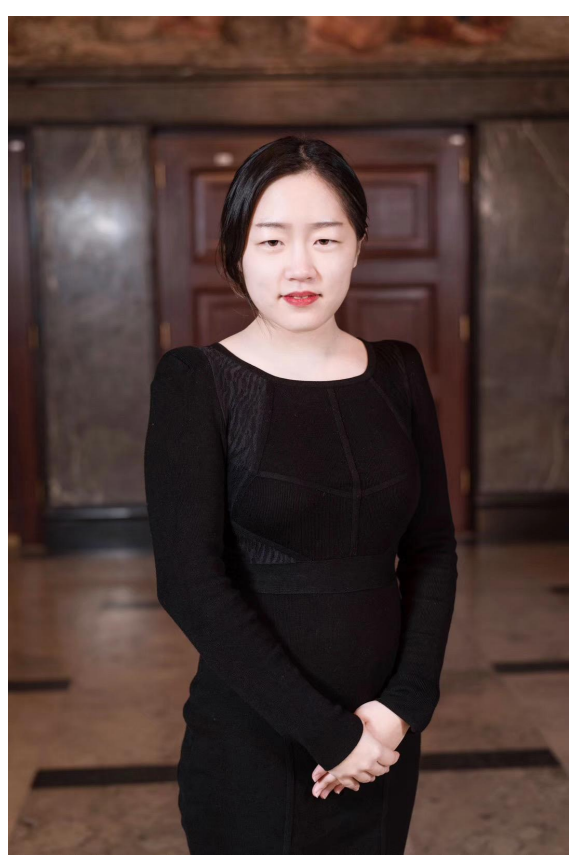

